\title{
Radiotracers and Nucleonic Control Systems Applied in Industry-Polish Case
}

\author{
Andrzej G. Chmielewski, Tomasz Smoliński, Marcin Rogowski \\ Institute of Nuclear Chemistry and Technology (INCT), Warsaw, Poland \\ Email: a.chmielewski@ichtj.waw.pl
}

How to cite this paper: Chmielewski, A.G., Smoliński, T. and Rogowski, M. (2019) Radiotracers and Nucleonic Control Systems Applied in Industry-Polish Case. World Journal of Nuclear Science and Technology, 9, 27-66.

https://doi.org/10.4236/wjnst.2019.92003

Received: February 11, 2019

Accepted: March 4, 2019

Published: March 7, 2019

Copyright $\odot 2019$ by author(s) and Scientific Research Publishing Inc. This work is licensed under the Creative Commons Attribution International License (CC BY 4.0).

http://creativecommons.org/licenses/by/4.0/

\begin{abstract}
Nuclear and radiation technologies play an important role in Polish power sector, oil industry and mining sector, starting from fossil fuels exploitation, their transport and distribution and finally power generation. Application of environmental isotopes, stable and radioactive, in ground water monitoring in the vicinity of open cast lignite mine, and radon monitor applied for miner's safety in deep coal mines and nucleonic control systems for ash in coal quality control is often used in mining industry. Other applications of nuclear techniques reviewed, concern the oil industry, oil field recovery, transportation pipelines and refineries. Finally, the application of beta radiation-based gauges for air borne fly ash monitoring and radiation technology for flue gas treatment are the examples of using this technique in power sector equipped with coal and oil fired boilers [1]. The radiotracers techniques were used also in glass industry (determination and optimization parameters of the furnaces), cement industry (test of aggregates for the production of cement and optimization media transport in pipelines), metallurgy of $\mathrm{Cu}, \mathrm{Pb}, \mathrm{Zn}$ (investigation of pyrometallurgy processes and new techniques), cellulose industry, environmental and (mainly hydrological) research etc. [2]. The article is brief review of present status of radiotracer and nucleonic gauges techniques as applied to polish industry.
\end{abstract}

\section{Keywords}

Radiotracers, Nucleonic Control Systems, Coal Mining, Oil Industry

\section{Introduction}

First application of nuclear techniques in Poland was reported nearly 45 years ago, and in 1961, about 200 radioisotope gauges were already installed in Polish industry [3]. During the next thirty years, manufacturing, installation and servicing facilities have been built enabling application of the nucleonic control 
systems (NCS) and radiotracer techniques in the industry on the relatively large scale [4]. A main sector where radiation and nuclear technologies in Poland are used:

- Medical sealed sources and accelerators,

- Industrial and geological field research,

- Radioisotope gauges,

- Industrial and research laboratories (open sources),

- Industrial and research laboratories (sealed sources),

- Production, transport and sales of radioactive materials.

Since the 90's decade, profound reconstruction of the Polish economy has started. Introduction of the market economy rules, the gradual introduction of new regulations on the use of radioisotopes and development of new non-radioisotope technologies caused reduced demand from the industry on the radiotracer testing. Such situation influenced that radiotracer techniques had to be considerably reduced. Moreover, competition of the other techniques, strict environmental protection standards and the rise of the anti-nuclear movements had significant impact on the position of radiotracer techniques.

At the moment radiotracers for industrial application mainly are used for leakage tests in refinery (INCT group). Metals recovery application investigated by radiotracers methods are under development as well [5] [6]. Radiometric methods are used also for waste water treatment application [7]. Sealed sources technologies such as: production and application of radioisotope gauges used for measurements and/or automatic control of such quantities as level, density, thickness, coating thickness, mass flow, ash content, acid concentration and airborne dust are still used as well. There are some specific branches of industry where "traditionally" nucleonic gauges are readily installed, such as sugar-factories (density), sulfuric acid production lines (concentration gauges) or coal mines (ash). The numbers of licenses for using radioisotope and radiation sources are shown in Table 1.

\section{Present Status of Radiotracer and Nucleonic Gauges Techniques as Applied in Industry}

The short summary of the present status of using radiotracers and NCS in Poland is showed in Table 2 .

\subsection{Radionuclide Source}

National Centre or Nuclear Research POLATOM Radioisotope Centre [8] is a Polish manufacturer and distributor of the isotope used in medicine, science, industry and environmental protection. The Centre produces wide range of products for medicine and for research, and development, technology and environment protection such as:

- Radiopharmaceuticals for diagnostic and therapy,

- Kits for labelling with Tc-99m,

- Radiochemicals (pharmaceutical grade), 
- Radiopharmaceutical precursor (for the radiolabeling of carrier molecules),

- Radionuclide generators,

- Wide range of radiochemicals,

- Sealed radiation sources for gamma radiography and industrial process control, (Ytterbium-169, Selenium-75, Iridium-192, Cobalt-60),

- Standard solutions and sources for electronic measurement devices calibration.

Radioisotopes in Poland are produced at MARIA research nuclear reactor which is currently the sole operated in Poland. Its power amounts to $30 \mathrm{MW}$. Current main reactor applications [9]:

Table 1. According to data of the National Atomic Energy Agency, the following numbers of licenses for using radioisotope and radiation sources were issued till the end of 2016 [3].

\begin{tabular}{|c|c|c|c|}
\hline Activity type & Symbol & $\begin{array}{c}\text { Number of } \\
\text { entities }\end{array}$ & $\begin{array}{l}\text { Number of } \\
\text { activity types }\end{array}$ \\
\hline Class I laboratory & I & 1 & 1 \\
\hline Class II laboratory & II & 94 & 107 \\
\hline Class III laboratory & III & 124 & 242 \\
\hline Class Z laboratory & $\mathrm{Z}$ & 108 & 199 \\
\hline Smoke detector service & UIC & 372 & 372 \\
\hline Device service & UIA & 168 & 197 \\
\hline Isotope devices & $\mathrm{AKP}$ & 556 & 696 \\
\hline Manufacture of isotope sources and devices & PRO & 28 & 32 \\
\hline Trade in isotope sources and devices & DYS & 76 & 85 \\
\hline Accelerator & $\mathrm{AKC}$ & 77 & 156 \\
\hline Isotope applicators & APL & 37 & 53 \\
\hline Telegamma therapy & TLG & 5 & 5 \\
\hline Radiation device & URD & 36 & 37 \\
\hline Gamma graphic apparatus & DEF & 111 & 113 \\
\hline Storage facility of isotope sources & MAG & 120 & 145 \\
\hline Work with sources outside registered laboratory & TER & 56 & 62 \\
\hline Transport of sources or waste & TRN & 488 & 499 \\
\hline Chromatograph & CHR & 227 & 275 \\
\hline Veterinary $\mathrm{X}$-ray apparatus & RTW & 1083 & 1128 \\
\hline $\mathrm{X}$-ray scanner & RTS & 471 & 609 \\
\hline $\mathrm{X}$-ray defectoscope & RTD & 206 & 229 \\
\hline Other X-ray apparatus & RTG & 399 & 592 \\
\hline Total & & & 5834 \\
\hline
\end{tabular}


Table 2. Status of radiotracer and nucleonic gauges in Poland.

\begin{tabular}{|c|c|c|}
\hline Radioactive source & Open sources & Sealed sources \\
\hline $\begin{array}{l}\text { Permission for the } \\
\text { application in the country }\end{array}$ & Yes & Yes \\
\hline Current status & Used & Used \\
\hline $\begin{array}{l}\text { Examples of present } \\
\text { application }\end{array}$ & Leakage tests in refinery & $\begin{array}{l}\text { Level gauges } \\
\text { Density gauges } \\
\text { Thickness gauges } \\
\text { Coating thickness gauges } \\
\text { Nucleonic balances (bulk flow meter) } \\
\text { Concentration gauge } \\
\text { Gamma scanning } \\
\text { Analyzers and monitors }\end{array}$ \\
\hline Requirements & $\begin{array}{l}\text { National Atomic Energy Agency } \\
\text { permission }\end{array}$ & $\begin{array}{l}\text { National Atomic Energy Agency } \\
\text { permission for use }\end{array}$ \\
\hline $\begin{array}{l}\text { Special requirements and } \\
\text { restrictions }\end{array}$ & $\begin{array}{l}\text { Provincial Sanitary and } \\
\text { Epidemiological Station } \\
\text { permission } \\
\text { Office of Technical Inspection } \\
\text { permission for pressure tests }\end{array}$ & $\begin{array}{l}\text { Certificates } \\
\text { PN-EN norms, ISO standards }\end{array}$ \\
\hline
\end{tabular}

- Production of radioisotopes,

- Testing of fuel and structural materials for nuclear power engineering,

- Neutron transmutation doping of silicon,

- Neutron modification of materials,

- Research in neutron and condensed matter physics,

- Neutron radiography,

- Neutron activation analysis,

- Neutron beams in medicine,

- Training in the field of reactor physics \& technology.

\subsection{Present Examples of Using Radiotracer and Nucleonic Control Systems Applied to Industry}

\subsubsection{Leakage Tests}

The Institute of Nuclear Chemistry and Technology has been performing for many years in control of the leak-proof-ness of production systems and facilities, underground and ground tanks and underground gas and liquid pipelines by radioisotope marker methods. The field group comprises experienced staff, licensed by the National Atomic Energy Agency. They have got specialized equipment for field generation of various radioisotope markers suitable for marking different types of media. The hardware includes dosing and measuring equipment and detectors for leak-proof-ness tests performed by pig moving inside pipelines. They use special absorptive materials matching the markers [10].

The method is basing on filling the tested facility with (primarily) gaseous methyl bromide labelled with bromine $\mathrm{Br}-82$ (Figure 1). Following mixing with the control or working medium the marker flows to the leak site and is captured 
by either natural (soil, thermal insulation) or artificial (special materials installed before test) adsorbent. In case of soil adsorption, the marker migrates towards the surface. Radiometric detection can be carried out through layers of soil up to 5 meters thick and enables identification and precise positioning of the leak. Special follow-up detectors moving inside the pipeline together with the control medium are used for tests of underground pipelines with cleanout chambers. No absorbents are used for tests of valves and exchangers. They are performing leak-proof-ness tests including precise localization of leaks using radioisotope marker methods at [11]:

- underground liquid and gas pipelines ( $\Phi 200-600 \mathrm{~mm}$ ) with cleanout chambers-with sensitivity of up to $0.5 \mathrm{dcm}^{3} / \mathrm{h}$ for liquids and $5 \mathrm{~g} / \mathrm{h}$ for gases (output from the smallest detected at localized leak) and underground liquid and gas pipelines ( $\Phi \geq 600 \mathrm{~mm}$ ) without cleanout chambers-with sensitivity of up to $1.0 \mathrm{dcm}^{3} / \mathrm{h}$ for liquids and $10 \mathrm{~g} / \mathrm{h}$ for gases,

- underground and ground pipelines (of all diameters) for gas and liquids without cleanout chambers with sensitivity up to $1.0 \mathrm{dcm}^{3} / \mathrm{h}$ for liquids and $10 \mathrm{~g} / \mathrm{h}$ for gas (Figure 2),

- gate valves in pipelines for all media,

- underground tanks and ground tank bottoms with sensitivity related to the tank volume,

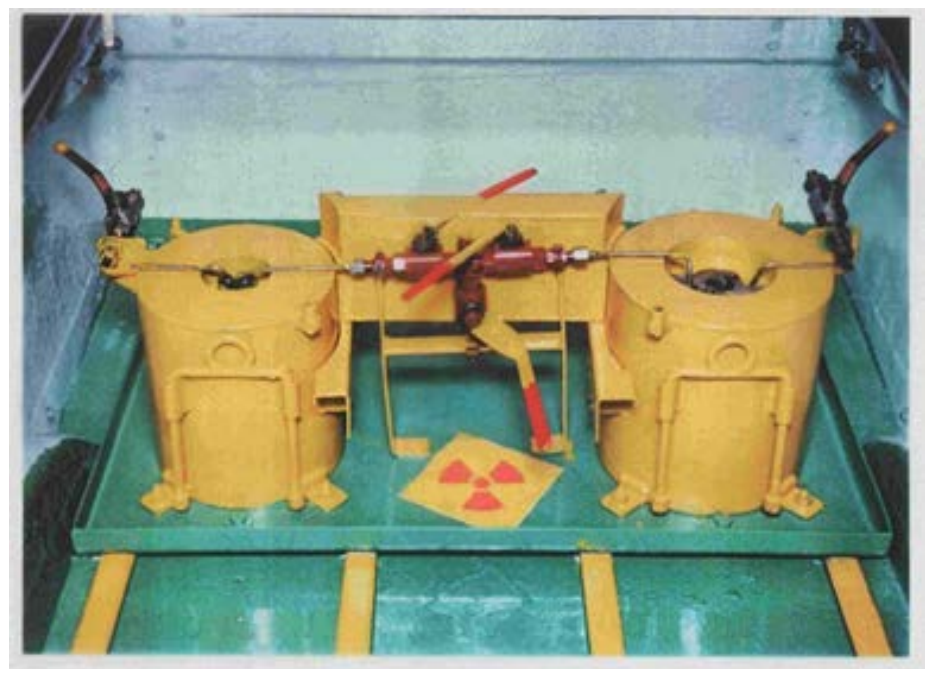

Figure 1. Equipment needed for generation of gaseous methyl bromide from pre-activated potassium bromide.

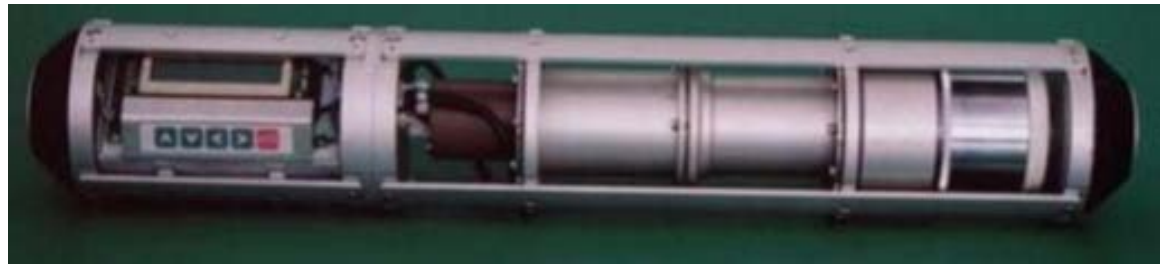

Figure 2. Detector for detection of leaks in underground pipelines with cleanout chambers. 
- petrochemical and chemical industry installations with sensitivity of $30 \mathrm{~cm}^{3} / \mathrm{h}$. Tests are performed without removal of inner and outside lining, installation of scaffoldings and removal of catalysts,

- other installations and structures subject to individual arrangements.

The methods are recognized by the Office of Technical Inspection. A long experience gained during various projects carried out for PKN Orlen Płock, Gdańsk Refinery, Przedsiębiorstwo Eksploatacji Rurociągów Naftowych (PERN) in Płock and other clients stands evidence to the quality of results and efficiency of the method. In terms of costs, using radioisotope markers for leak-proof=ness tests is cheaper than traditional methods.

\subsubsection{Radiotracer in Biotechnology Process Investigations}

Radiotracer in the form of tritium water $\left(\mathrm{T}_{1 / 2}=4510\right.$ days, $\beta$ radiation -0.018 $\mathrm{MeV}$ ) was used for determination of residence time distribution (RTD) of materials in installation with $42 \mathrm{dm}^{3}$ volume and flow rate $0.6 \mathrm{dm}^{3} /$ day for biogas production during anaerobic digestion of selected agricultural material or municipal wastes. The scanning technique was applied for measurement of density distribution inside the fermenter and eventually presents of foam inside the fermenter (Figure 3) [12].

These experiments were a base for construction of industry scale technology for biogas generation $(230 \mathrm{~kW})$.

\subsubsection{Coal Mining Industry}

Sealed radioactive sources steel is used into polish coal mines. Examples of the use of radioisotope techniques in mines are presented below (Figure 4 and Figure 5).

Carbon enrichment involves the separation of coal from the stone. This occurs in a thick suspension fluid. To maintain the appropriate density of this liquid, isotopic densitometers are used. The densitometers are most often used when measuring the density of the product flowing in pipeline, detector and container with the source are mounted on a special frame, after both sides of the pipe and is part of the pipeline [2].

\section{Regulations on Radiation Protection and Use of Radiation}

\subsection{Legal Basis}

The legal basis for regulating the use of radioactive materials is: Atomic Law. Act of Parliament of 29 November 2000 on the Atomic Law introduced a consistent system ensuring nuclear safety and radiological protection of workers and general public in Poland [14].

Key provisions of the Atomic Law Act regard licensing of activities which involve exposure to ionizing radiation (i.e. licenses issued for activities specified in section "Definition, structure and functions of nuclear safety and radiological protection system") [15], powers vested within heads of organizational entities conducting activities with the use of radiation and powers of the President of 

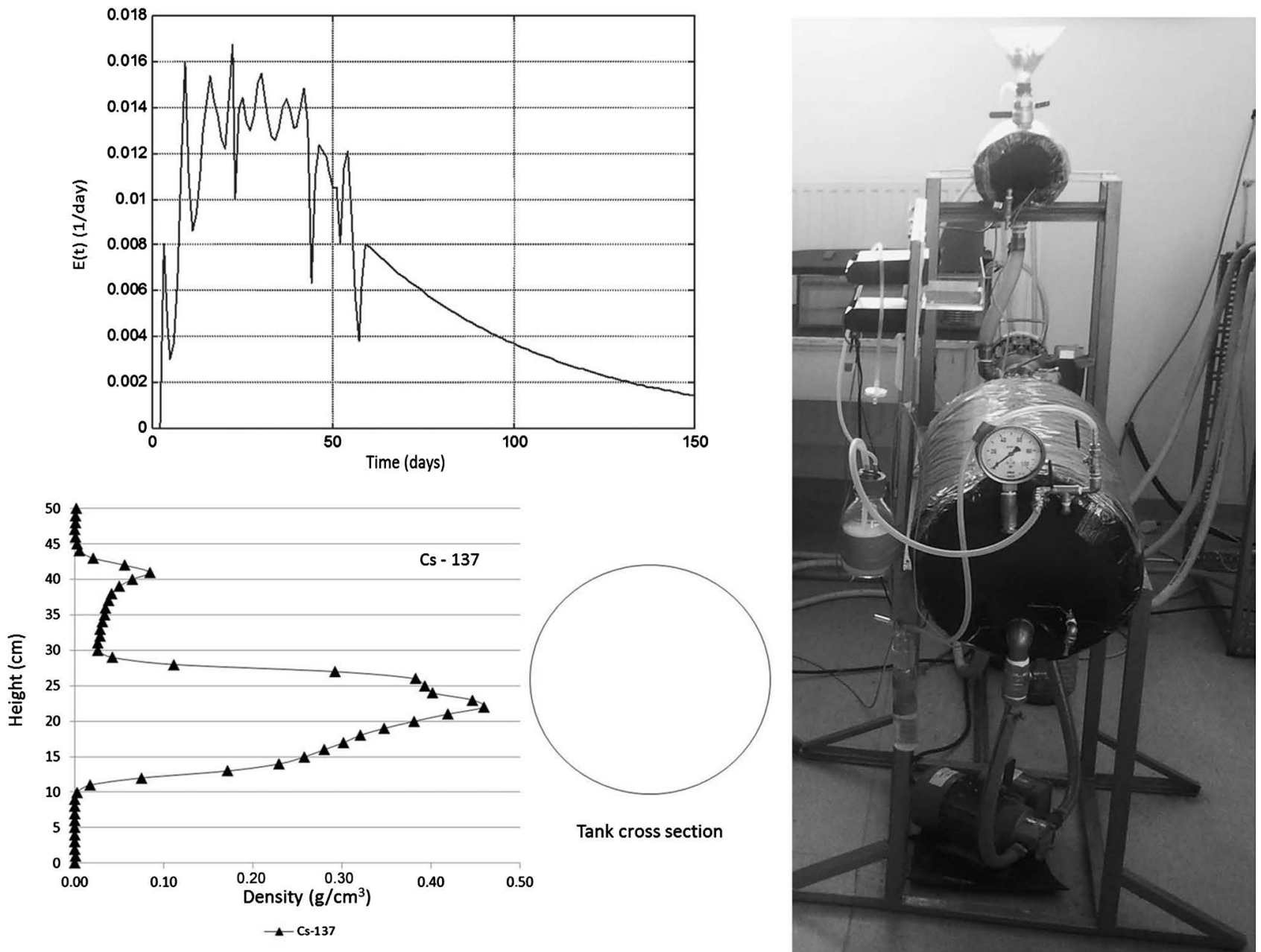

Figure 3. Comparison of experimental and model RTD results and scheme of scanning measurement and distribution of the density inside the fermenter [12].

1. Belt conveyor,

2. Dump truck,

3. The trolley drive actuator,

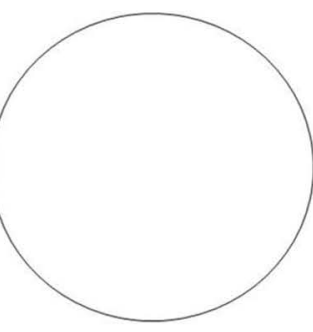

Tank cross section

4. Redundant pocket,

5. Radiation source.

6. Detector.
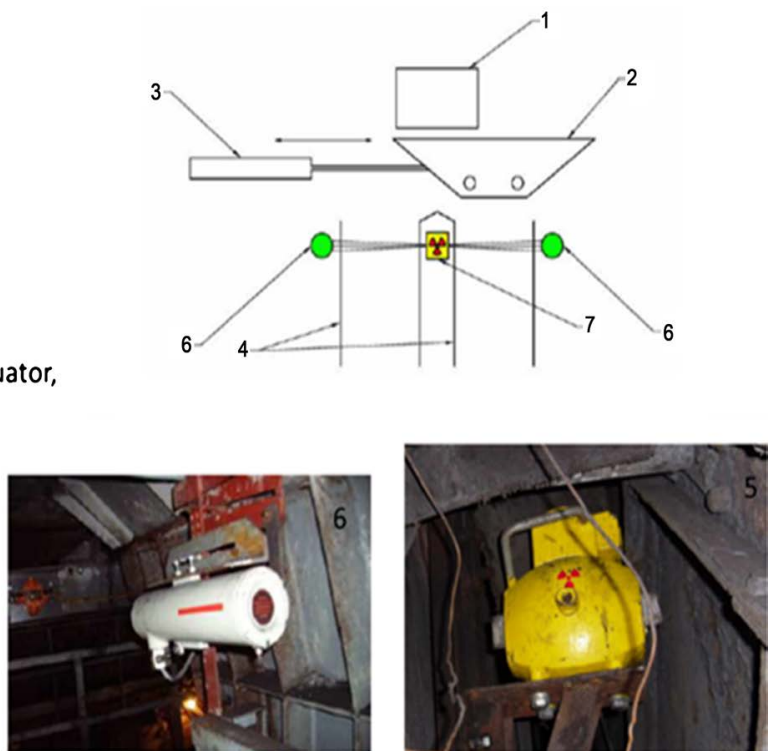

Figure 4. Loading of skip pocket [13]. 

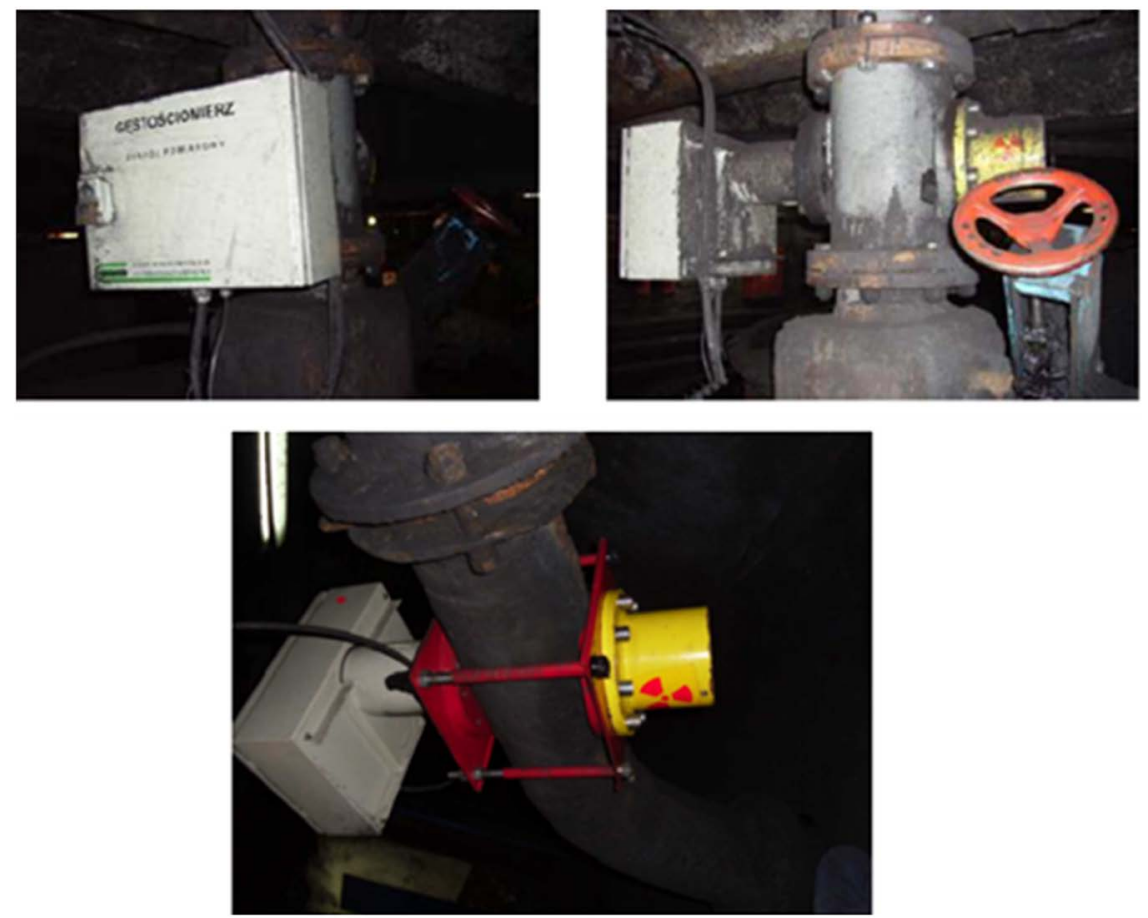

Figure 5. Density gauges into coal enrichment installation (source Cs-137) [13].

National Atomic Energy Agency to control and supervise these activities. The Act also identifies other tasks of the PAA President concerning, inter alia, assessment of national radiation situation and procedures applied in radiation emergency. The most important provisions of the aforementioned Act concern issuance of licenses for activities connected with exposure to ionizing radiation (i.e. licenses for activities specified above in the subchapter "Definition, structure and functions of the nuclear safety and radiological protection system"), obligations of heads of organizational units conducting activities which involve radiation and prerogatives of the President of the National Atomic Energy Agency to exercise regulatory control and supervision of these activities [3].

Other Acts of Parliament

Apart from the Atomic Law Act, Polish laws set forth provisions indirectly connected with the issues of nuclear safety and radiological protection, which are included in other Acts of Parliament, in particular in [16]:

- Act of Parliament on Shipment of Hazardous Goods,

- Act of Parliament on Marine Safety,

- Act of Parliament on Technical Supervision,

- Plus 34 secondary legislation to the Atomic Law for example:

- Regulation of the Council of Ministers of July 12, 2006 on detailed conditions of safe work with sources of ionizing radiation (Journal of Laws from 2006 No. 140 item 994),

- Regulation of the Council of Ministers of December 23, 2002 on the requirements for dosimetric equipment (Journal of Laws of 2002 No. 239, item 2032), 
- Regulation of the Council of Ministers of December 3, 2002 on radioactive waste and spent nuclear fuel (Journal of Laws of 2002 No. 230 item 1925),

- Regulation of the Council of Ministers of February 20, 2007 on basic requirements for controlled and supervised areas (Journal of Laws of 2007 No. 131, item 910).

\subsection{How to Perform Industrial Research Using Radioisotopes in Poland-An Example of a Path}

The first step is to get permission for work with isotopes from the PAA President [17].

Drafts of the PAA President's licenses for performance of activities involving exposure to ionizing radiation and other decisions in matters considered important for nuclear safety and radiological protection were prepared by the Radiological Protection Department (DOR) of PAA. Issuance of a license, an annex to a license or receipt of a notification is always preceded by the analysis and assessment of the documentation submitted by users of ionizing radiation sources. Apart from the said documentation, a detailed analysis is also conducted to cover the following issues: substantiation for the commencement of the activity involving exposure, utility dose limits proposed, quality assurance program in connection with the activity conducted Supervision of the use of ionizing radiation sources and an internal emergency plan for cases of radiation emergency. In cases, in which activity involving ionization radiation exposure does not require a license, decisions are issued on acceptance of notification of activity involving exposure to ionizing radiation. These cases have been listed in the Regulation of the Council of Ministers of 6 August 2002 concerning cases, in which activity involving exposure to ionizing radiation is not subject to the license or notification obligation and cases, in which it may be conducted on the basis of a notification (Journal of Laws No. 137, item 1153 as amended).

In the application for a permit, there must be a description of the test procedure-Technological Instruction. There is a description of the isotope and its form, activity, radioactive waste management, justification of the method, possessed dosimetry equipment, type of source (open, closed), name of the tested installation, what will be tested, how and by what method, how the activity measurement will be performed. With the use of unsealed sources, special attention should be paid to storage and handling of sources and to the potential for contamination of workers and equipment.

The procedure differs slightly when sealed radioactive sources is used. Heads of organizational units performing activity which involves use or storage of sealed radioactive sources or equipment featuring such sources under the relevant authorization granted are obliged to submit copies of records concerning the radioactive sources to the PAA President. Such documents include record sheets containing the following data about sources: radioactive isotope name, activity according to a source certificate, date when the activity was established, certificate number and source type, storage vessel type or device name and place 
of the source use or storage. It is also needed emergency procedure if the source is unsealed. Data extracted from the accountancy cards are entered into the register of sealed radioactive sources, used to verify information about individual sources. The information contained in the said register is used to supervise organizational units conducting activity involving exposure to ionizing radiation. The supervision consists in comparing accountancy cards entries with the scope of the given authorization issued.

The application is verified by the Nuclear Supervision Inspector. After the substantive analysis, a permit is issued.

The second step of "the path" is preparation of Technical Procedure of the planned work. This document needs:

- Positive opinion of the competent State Sanitary Inspector of technological work instructions,

- Permission of the PAA President to conduct works radioactive source in the field,

- Written consent of the site administrator to perform works on its premises with source of radiation,

- Notification of the competent State Sanitary Inspector on the date and place of performing works with radioactive source,

- The program of protection against ionizing radiation in the transport of radioactive materials,

- Emergency plan.

Certain types of measurements (e.g. leak tests under pressure) may require additional permits such as: Office of Technical Inspection permission for pressure tests. Such permission requires the preparation of many additional documents and procedures, and the UDT certificate procedure may take up to 12 months!

In the next step radioisotope must be ordered from supplier (Maria Reactor) and transported to the laboratory for synthesis of radiotracer (if needed). The contractor performing work with the isotope must be equipped with a radiological laboratory. A special transport must be organized to deliver the isotope to the laboratory and test site.

Only a qualified employee may be allowed to work with the isotope. During fieldwork, a radiological protection inspector must attend them all the time. After completing the work, the inspector has to perform dosimetry measurements and prepare report for PAA inspector.

Additional information:

Radioactive waste: if a short-lived isotope is used for tests, it is waiting for its expiration. If it is a long-lived isotope, the waste should be collected and transported to the Radioactive Waste Management Plant,

Open sources: usually the activity of the initial isotope is strictly limited, so that after it's spreading in the installation its activity decreases below the norm of acceptable contamination,

Time: the measurements on the site in case leak detections take $1-2$ weeks 
but whole procedure with may take even several months.

Permissions: The Laboratory of Diagnostic Methods at INCT has PAA permission and UDT certificate, which is valid for 2 years (Figure 6). It authorizes to carry out research in the field-leak testing of technical facilities using isotope tracers. Technical devices and objects in industrial installations may be examined like petrochemical and chemical, e.g. pipelines, apparatus, columns, exchangers, boilers, etc.

\subsection{Norms and Standards Used in Poland [18]}

- PN-EN ISO/IEC 17025 General requirements for the competence of testing and calibration laboratories,

- ISO 2975/I-1976 Measurement of water flow in closed conduits-Tracer methods-Part I: General,

- ISO 2975/III-1976 Measurement of water flow in closed conduits-Tracer methods-Part III: Constant rate injection method using radioactive tracers,

- ISO 553/3-1982 Liquid flow measurement in open channels-Dilution methods for measurement of steady flow-Part 3: Constant rate injection method and integration method using radioactive tracers,

- PN-ISO 7205:1997 Isotopic control and measurement devices-Fixed devices,
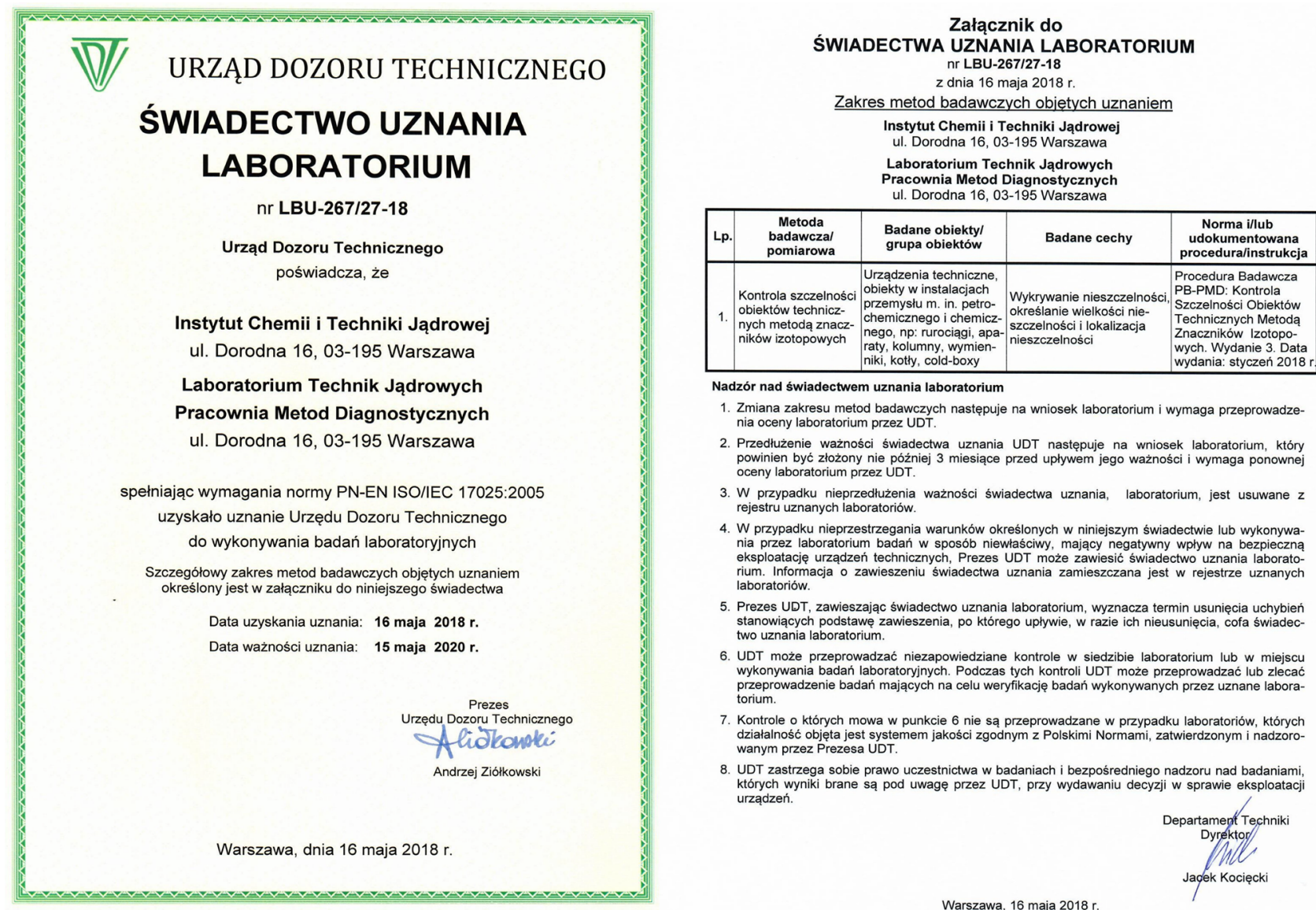

Figure 6. UDT Certificate. 
- PN-EN 60846:2004 Apparatus of radiation protection. Meters and/or monitors for the spatial and/or directional equivalent dose (or power) of beta, $\mathrm{X}$-ray and gamma radiation,

- PN-EN 60846:2004 Apparatus of radiation protection. Measurement of individual $\mathrm{Hp}(10)$ and $\mathrm{Hp}$ (0.07) dose equivalent of X-rays, gamma, neutron and beta radiation. Direct reading of individual dose equivalent measures,

- PN-EN 60325:2007 Instrumentation for radiological protection. Meters and monitors of radioactive contamination, alpha, beta and alpha/beta (beta energy > $60 \mathrm{keV}$ ),

- PN-ISO 9978:1999 Radiological protection-Closed-cell radioactive sources-Leak testing methods.

\section{Local Companies, Manufacturing NCS and Institutions}

\subsection{Institute of Nuclear Chemistry and Technology (INCT) [19]}

(Instytut Chemii i Techniki Jądrowej) Dorodna 16, 03-195 Warsaw, Poland http://www.ichtj.waw.pl, phone: +48 2250410 00, e-mail: sekdyrn@ichtj.waw.pl. Services:

- Detection irradiated foods,

- Radiation Sterilization Plant,

- Nuclear Techniques Laboratory, Diagnostic Methods Group:

- underground liquid and gas pipelines $(\Phi 200-600 \mathrm{~mm}$ ) with cleanout chambers-with sensitivity of up to $0.5 \mathrm{dcm}^{3} / \mathrm{h}$ for liquids and $5 \mathrm{~g} / \mathrm{h}$ for gases (output from the smallest detected at localized leak) and underground liquid and gas pipelines ( $\Phi \geq 600 \mathrm{~mm}$ ) without cleanout chambers-with sensitivity of up to $1.0 \mathrm{dcm}^{3} / \mathrm{h}$ for liquids and $10 \mathrm{~g} / \mathrm{h}$ for gases,

- underground and ground pipelines (of all diameters) for gas and liquids without cleanout chambers with sensitivity up to $1.0 \mathrm{dcm}^{3} / \mathrm{h}$ for liquids and $10 \mathrm{~g} / \mathrm{h}$ for gas,

- gate valves in pipelines for all media,

- underground tanks and ground tank bottoms with sensitivity related to the tank volume,

- petrochemical and chemical industry installations with sensitivity of $30 \mathrm{~cm}^{3} / \mathrm{h}$. Tests are performed without removal of inner and outside lining, installation of scaffoldings and removal of catalysts,

- other installations and structures subject to individual arrangements,

- Laboratory of Nuclear Analytical Methods,

- Food and Environmental Laboratory, Other activities are presented in [4] [5] [6] [7] and [20] [21].

\subsection{National Centre or Nuclear Research (NCBJ) [22]}

(Narodowe Centrum Badań Jądrowych) Str. Andrzeja Sołtana 7, 05-400 Otwock, Świerk, Poland https://www.ncbj.gov.pl/en, phone: +48 222731 001, e-mail: ncbj@ncbj.gov.pl. 
NCBJ offers a broad range of research/engineering services for both domestic and foreign customers. They have accumulated vast experience in producing ionizing radiation detectors and materials for their construction; the detectors are used by the most eminent equipment manufacturers and research labs in the world. They have been constructing unique electronic instruments to cooperate with ionizing radiation detectors, including individual circuits and entire systems for LHC in CERN, Geneva, which is the largest research facility built by the mankind. The Institute is also operator of the Maria Reactor. The part of the institute is POLATOM Radioisotope Centre which is a Polish manufacturer and distributor of the isotope used in medicine, science, industry and environmental protection. Research is a research and development. The Centre produces wide range of products for medicine and for research and development, technology and environment protection.

\subsection{EMAG [13]}

Institute of Innovative Technologies EMAG, and Centre of Technology Transfer EMAG Ltd. (CTT EMAG, http://www.cttemag.pl/, Leopolda 31, 40-189 Katowice).

For over 40 years, the Institute of Innovative Technology EMAG has specialized in the development and construct of systems and equipment for on-line monitoring and laboratory measurements of coal quality parameters, as well as in the implementation of these devices in mines and power plants. The systems based inter alia on the radiation detection techniques, such as: backscattering of gamma radiation (ALFA-06 and ALFA-06/T systems) and absorption of a dual energy gamma ray transmission (ALFA-06/2E ash meter, ALFA-06/3E system), have found wide application in Poland. At present, over 100 systems and devices for analysis are used in Polish hard and brown coal mines.

ALFA-06/T-ash meter and calculating calorific value, use backscattering.

ALFA-06/2E-on-line ash monitor, use absorption of a dual energy gamma ray transmission. Makes it possible to measure ash content in coal with a grain size of $0-200 \mathrm{~mm}$ and in carbon layers with a thickness of $50-300 \mathrm{~mm}$. The ash content is determined by measuring the attenuation of two concentrated beams of radiation passing through the coal layer, which come from two different radiation sources placed between the conveyor belts. This ash meter can be used in a situation where different coal sizes lie on a belt in a layered system.

ALFA-06/3E-Absorption system for on-line monitoring of coal quality (ash content, moisture) and calculating calorific value of coal transported on conveyor belt. Use absorption of a dual energy gamma ray transmission utilized in loading places and controlling the enrichment process (Figure 7).

Modern versions of density meters have been developed at the EMAG Centre. Accurate measurement of density and values being density functions for a substance with an altered chemical composition was obtained thanks to applied measuring method using of absorbing and scattering radiation gamma. A cha- 
racteristic feature of the meters is that the isotope gauge is an element a pipeline with an internal diameter equal to the internal diameter of pipeline. The EMAG Centre was developed several types of gauge intended for various applications. $\mathrm{C}$ and CA (caesium and americium) type isotope density meter are designed for measurement of high density substances.

C-type gauge provides continuous measurement of the density of substances transported by pipelines; measurement of other qualities of these substances calculated on the basis of the measured density (Figure 8).

Technical information:

- measuring method: gamma ray absorption,

- pressure of the measured substance: $\leq 1 \mathrm{MPa}$,

- outside diameter of the pipeline: $100-400 \mathrm{~mm}$,

- range of density measurement: $0.1-2.5 \mathrm{~g} / \mathrm{cm}^{3}$,

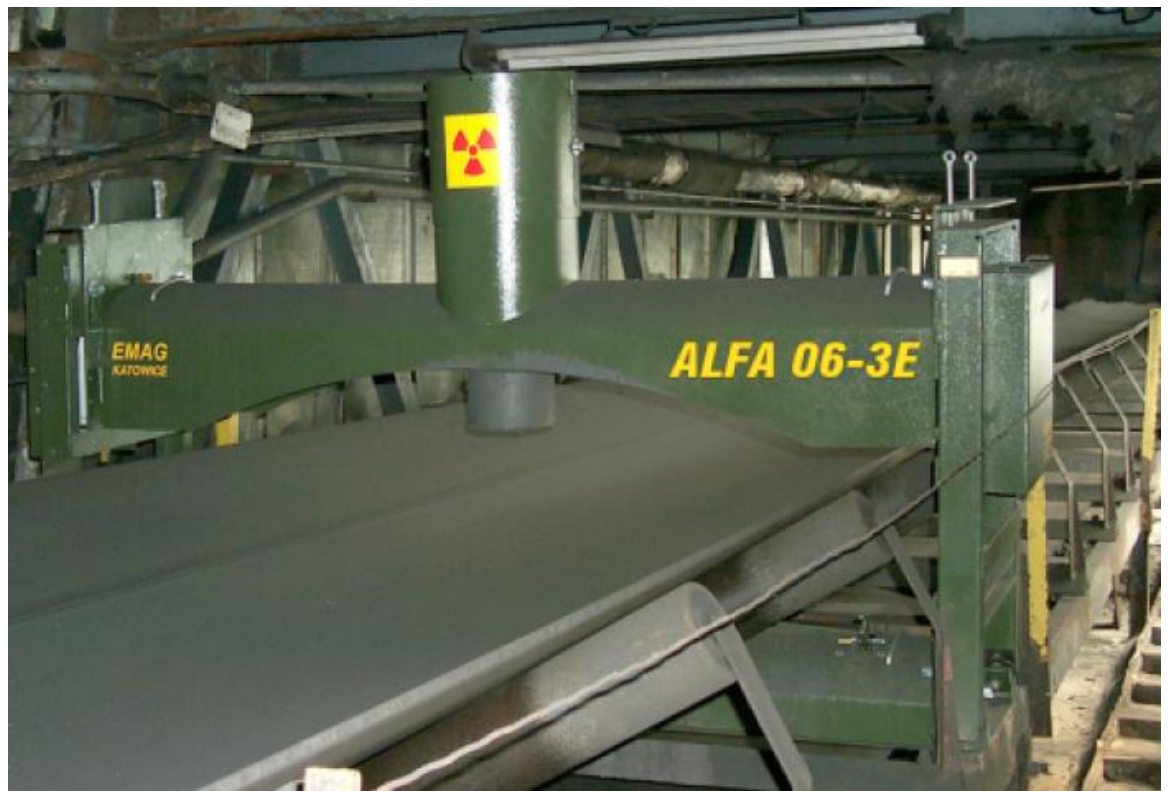

Figure 7. ALFA 06/3E at the coal processing plant Radiation source: $137 \mathrm{Cs}(0.555 \mathrm{GBq})$ and 241 Am (11.1 GBq) [13].
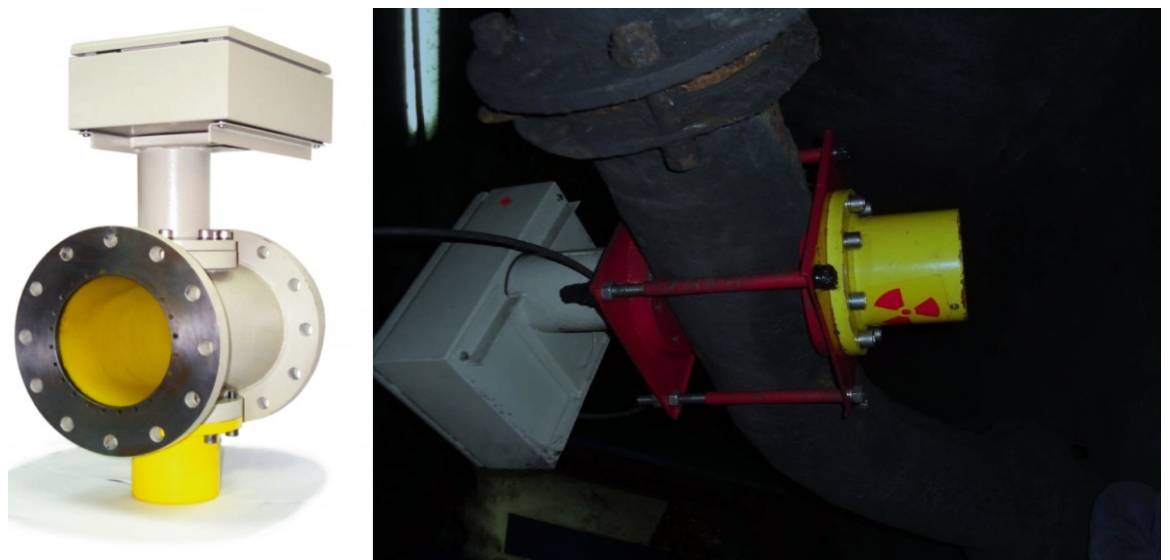

Figure 8. C-type isotope density meter [13]. 
- time of measurement: 3 - $100 \mathrm{~s}$,

- radiation source: Cs-137 with activity 37 - $555 \mathrm{MBq}(1-10 \mathrm{mCi})$.

$\mathrm{B}$ and BA (133Ba and 241Am) type density meter are provided for measuring of substances with slightly larger or smaller density than water.

CA-type density meter gauge was applied in "Jaworzno" mining where it is utilized for automatic control work of pumps which receive a concentrated sludge from a radial thickener and for control the process of preparing a backfilling mixture.

These devices ensure full safety of use-no restricted zone due to the use of isotope with very low activity. Application in automation systems process control:

- flotation,

- coal enrichment in a heavy liquid (especially C-type gauge),

- water and mud circuit,

- preparation and transport mixtures flooring.

Previously generation of devices produced by EMAG-MPKF radiometric ash meter: enable fast (100 s) measurement of ash content in samples with granulation 0 - $10(20) \mathrm{mm}$. The measurement is based on low-energy forward-scattering gamma rays of Am-241. This type of fully automated devices is used in $18 \mathrm{~min}$ ing plants to control the quality of raw coal and enrichment products (Figure 9).

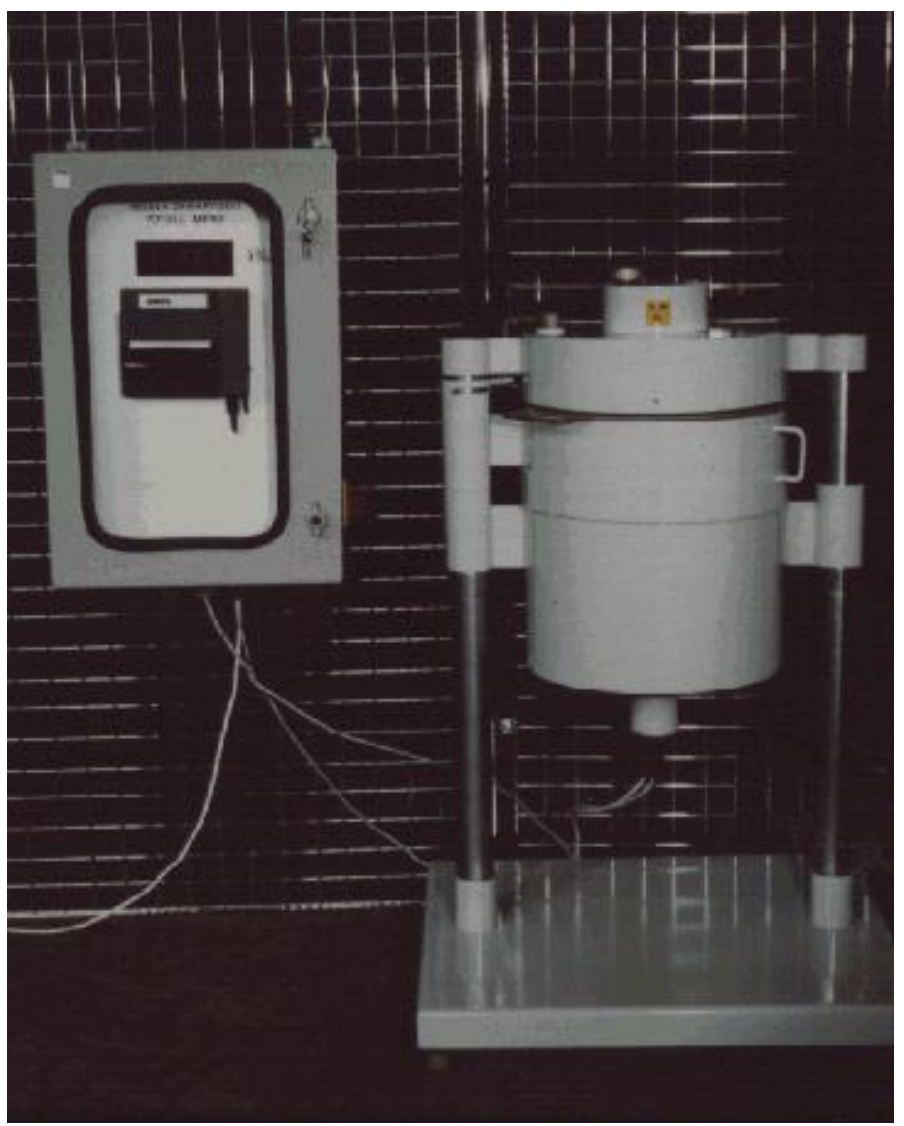

Figure 9. MPKF radiometric ash meter [13]. 


\subsection{Industrial Implementation Company “WILPO” Ltd. [23]}

Mikołowska 29, 41 - 400 Mysłowice (Poland), http://www.wilpo.pl/.

The company was founded in 1988 and offers stationary devices as well a series of on-line devices for work directly on belt conveyors and devices co-operating with coal samplers. In the field of on-line measuring, the WILPO offers a number of solutions, adapted to various installation and measurement conditions.

WILPO C 212-radiometric under belt ash meter (Figure 10) is especially prepared for ash content measurement in a run of a mine of hard and brown coal. It can be employed in an open pit (i.e. directly on excavators), power stations and mines. The WILPO C212UG version is the first ash meter in Poland approved for operation in underground conditions (sign WUG: DE-111/99).

Technical specifications:

- Granulation of tested carbon: 0 - $300 \mathrm{~mm}$,

- Required thickness of the carbon layer: $\mathrm{min}$. $100 \mathrm{~mm}$ (homogeneous, without a layer of coal),

- Radiation source: Cs-137 with activity 3.7 GBq.

WILPO C 411A - radiometric ash meter is designed for continuous measurement of the ash content in coal directly on the conveyor belt, especially in carbonaceous mixtures with a layered structure and in the coal with the layer height on the conveyor belt from 50 to $250 \mathrm{~mm}$ and grains up to $80 \mathrm{~mm}$ (Figure 11). The measurement is possible on sloping, reversing and even passable belts. The small size and the non-contact measurement method predispose it to be used in technological nodes of mines, as well as in power plants, heating plants, coking plants, etc.

Technical specifications:

- Coal type: hard and brown,

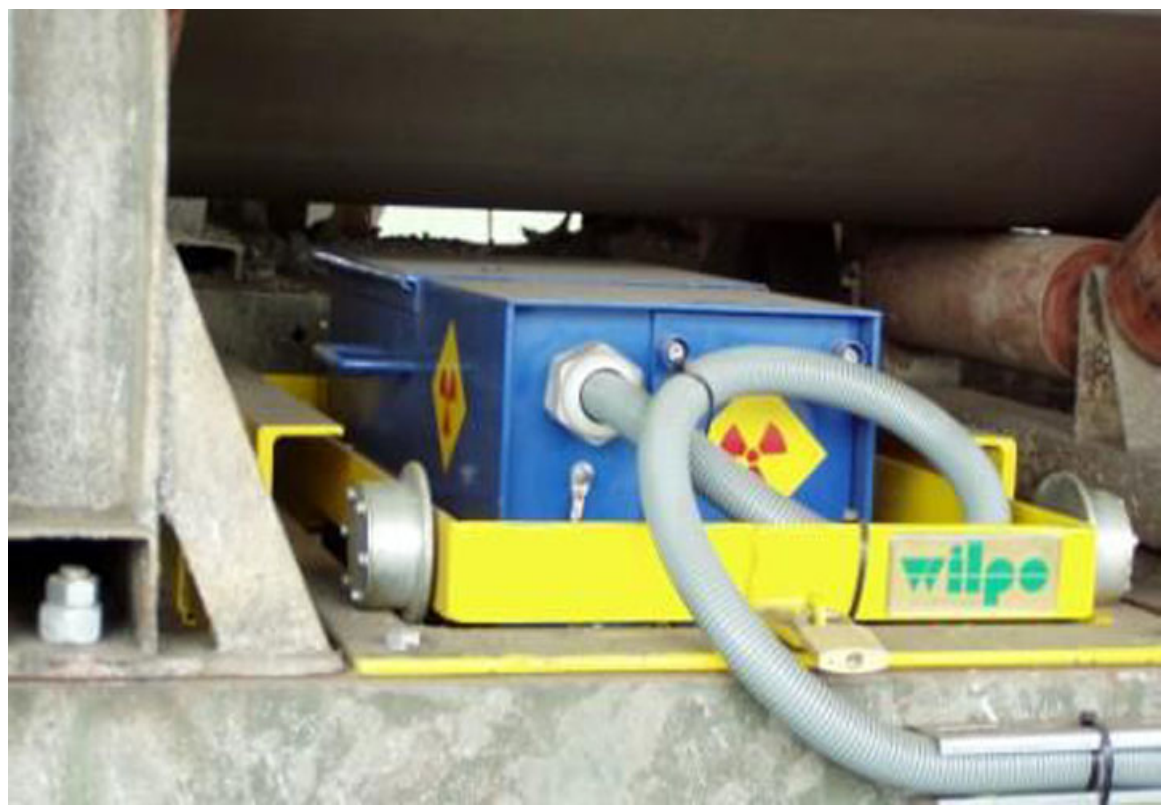

Figure 10. WILPO C 212 ash meter [23]. 
- Granulation of tested carbon: $0-80 \mathrm{~mm}$,

- Height of the carbon layer: 50 - $250 \mathrm{~mm}$,

- Radiation source: Am-241 (3.7 GBq and 40 kBq), Cs-137 with activity 3.7 GBq.

WILPO C 431-measuring system designed for on-line measurements of ash content, moisture content and determination of the calorific value directly on the conveyor belt (Figure 12). The basic applications of the system are related to the measurement possibilities, among others: carbon mixtures with a layered structure, variable granulation coal, technological nodes, points with relatively small amounts of coal, etc.

Technical specifications:

- Granulation of tested carbon: 0 - $80 \mathrm{~mm}$,

- Required thickness of the carbon layer: 50 - $250 \mathrm{~mm}$,

- Radiation source: Am-241 and Cs-137 with activity < 4 GBq.

WILPO C 512 and HC version-radiometric ash meters. Are intended for continuous measurements of ash content in hard (especially C $512 \mathrm{HC}$ ) and brown coal, for virtually any layer height and coal granulation, directly on a belt conveyor

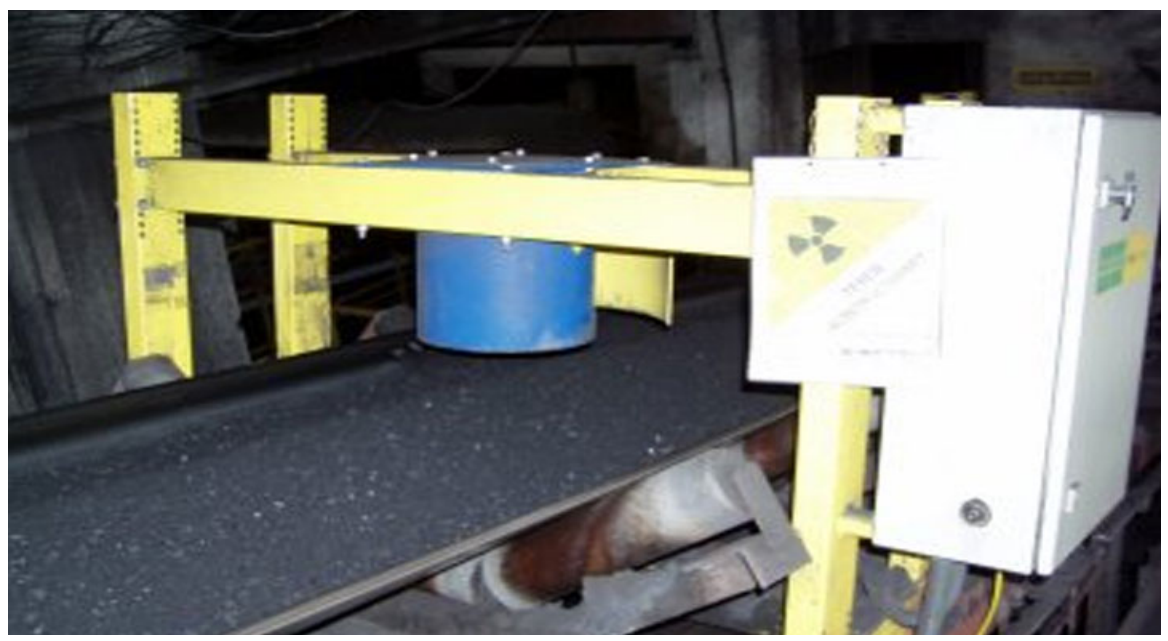

Figure 11. WILPO C 411A ash meter [23].

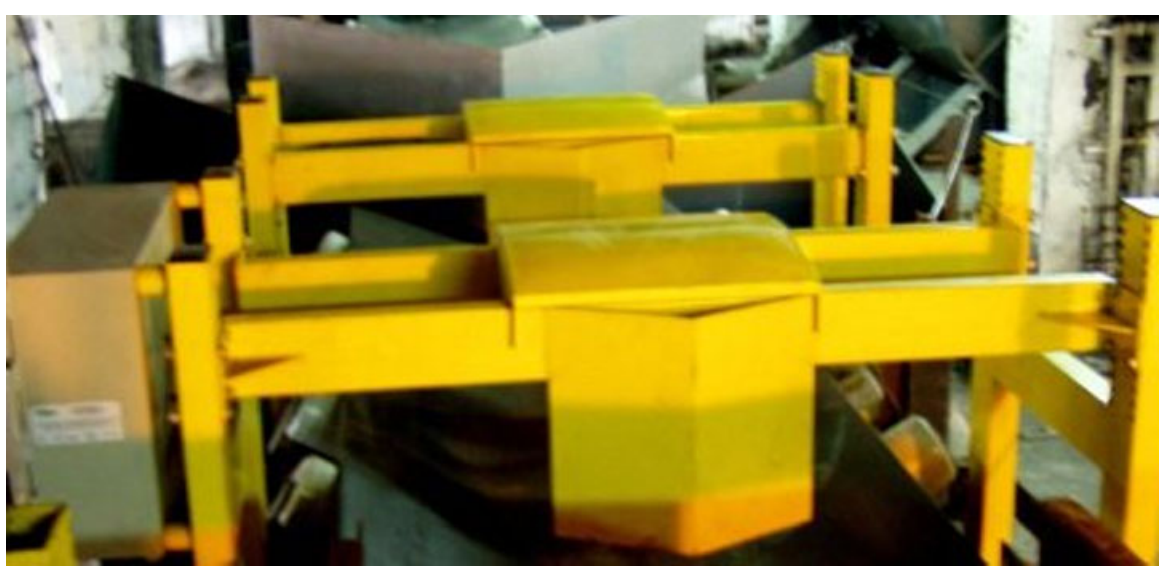

Figure 12. WILPO C 431 ash meter [23]. 
of any construction width. The innovative, scattering-absorbing measuring method used in the ash meter makes it possible to carry out measurements, which is a complete novelty, on conveyor belts with steel cords. This predisposes this type of ash meter for applications on long, open transport routes, especially in open-cast coal mines (Figure 13).

Technical specifications:

- Coal type: hard and brown,

- Granulation of carbon: 0-300 mm,

- Required thickness of the carbon layer: 100-500 (temporarily up to 750) $\mathrm{mm}$,

- Radiation source: Am-241 with activity 3.7-37 GBq (3.7 - 18.5 GBq for HC version).

WILPO C 532hc-coal quality parameters measurement system. Continuous measurement of ash content in coal is conducted using the innovative radiometric scattering and absorption method developed by WILPO in 2009 (Figure 14).

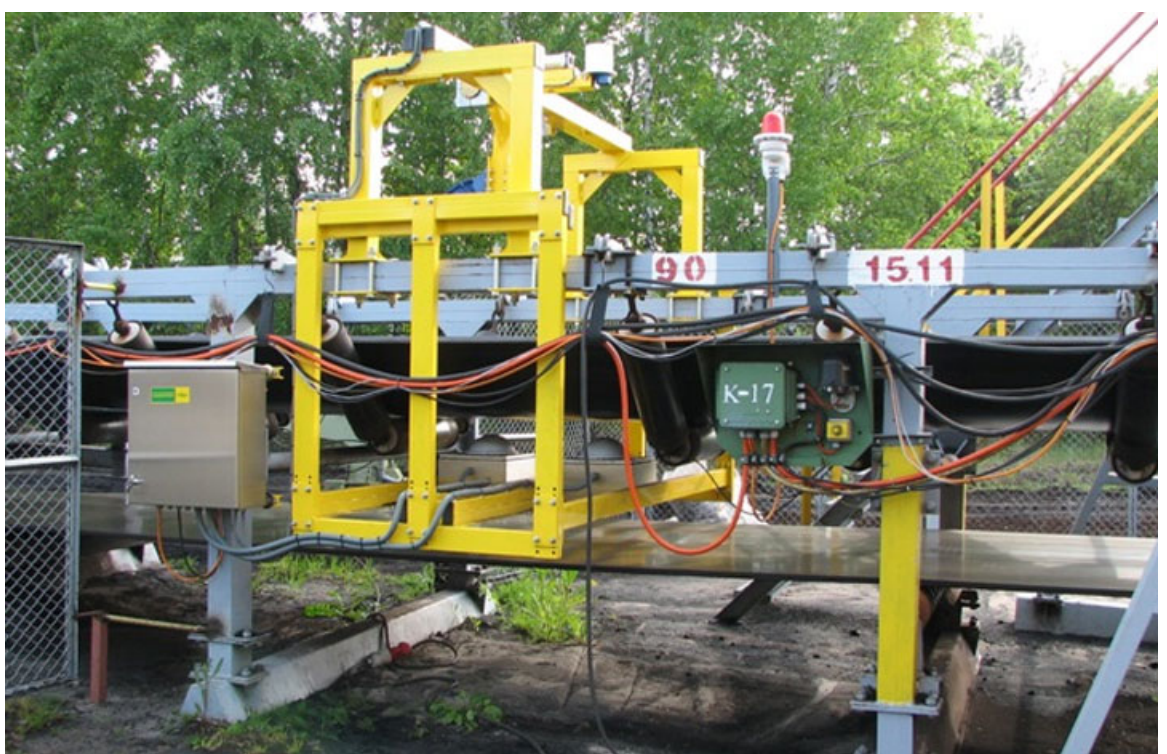

Figure 13. WILPO C 512 ash meter [23].
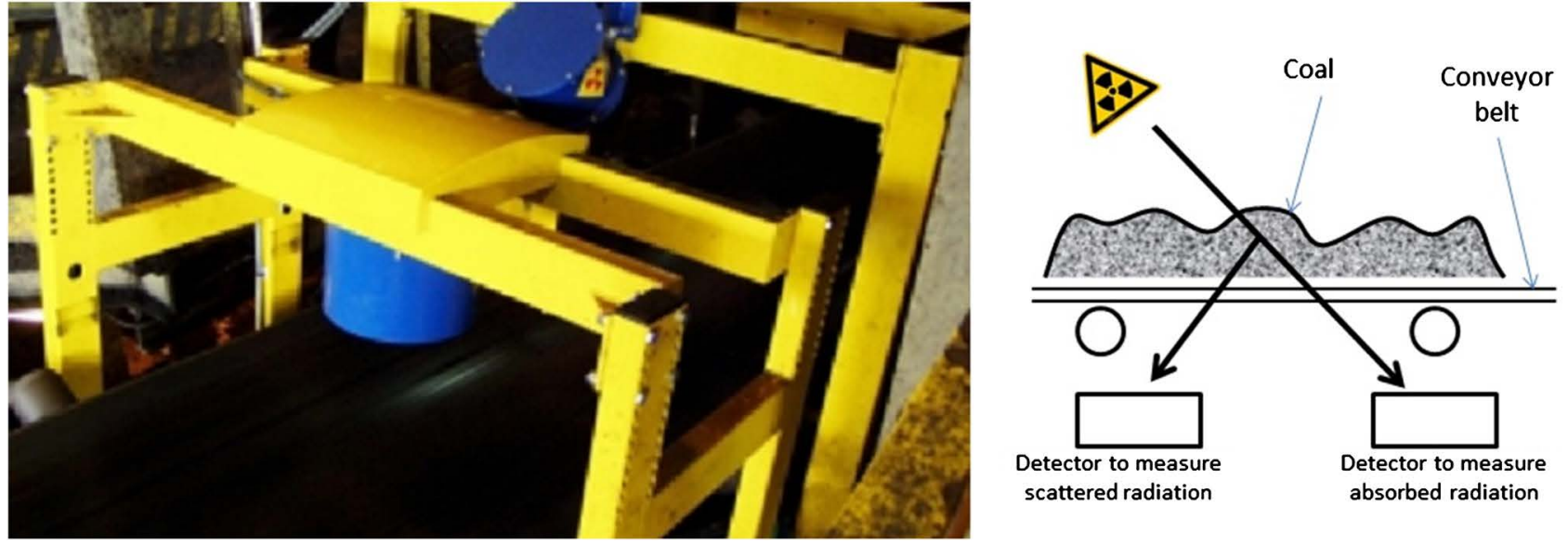

Figure 14. WILPO C 532 [23]. 
The method is based on irradiating a layer of coal (from above) with low-energy gamma rays and on recording the intensity of gamma radiation reaching a set of detectors arranged under the conveyor belt. Instead of one detector, a system of two appropriately positioned detectors has been introduced: one to measure scattered radiation, the other to measure absorbed radiation. This enabled the gathering of data on ash content variability and surface density of the coal analysed using one radiation source. The applied configuration provided measurement advantages which were unattainable until now, while retaining the valuable features of radiometric ash meters used before. Continuous measurement of moisture content in coal is carried out with use of the technology that consists in absorption of microwaves.

Technical specifications:

- Coal type: hard,

- Granulation of carbon: 0 - $70 \mathrm{~mm}$,

- Required thickness of the carbon layer: $50-250 \mathrm{~mm}$ (500 mm if only ash content),

- Radiation source: Am-241 with activity 3.7 - $18.5 \mathrm{GBq}$ and energy $60 \mathrm{keV}$.

The new design of the measuring system, most importantly that of the ash meter which includes a single and low-energy (60 keV) Am-241 radiation source, is perfectly safe. The device has been approved for manufacturing by WILPO by the Polish National Atomic Energy Agency (PAA) in Warsaw (permit No. D-17222 of 24 June 2009).

WILPO also holds a permit issued by PAA for the turnover, installation and transportation of equipment comprising sources of radiation (permit No. D-15512 of 14 January 2005, annex No.1 of 26 May 2008).

WILPO C 732 measurement system (Figure 15). This rapid measurement system of coal quality parameters which can cooperate with the samplers is designed

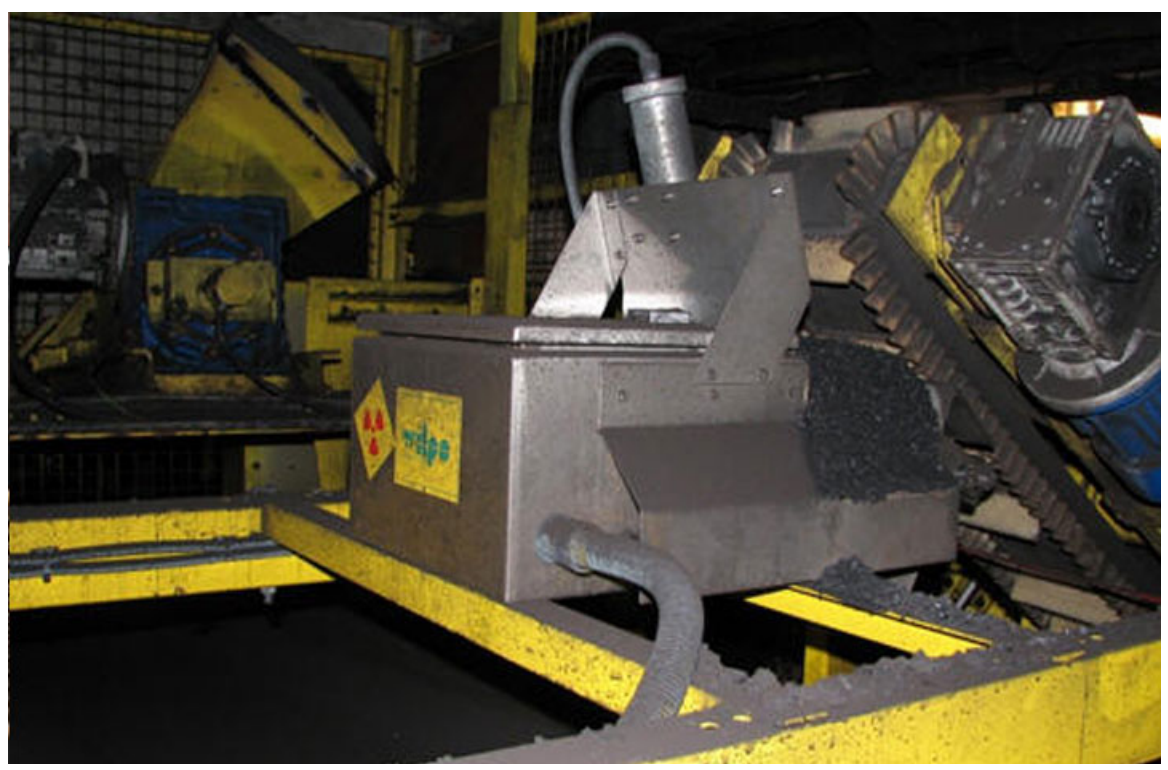

Figure 15. WILPO C 732 [23]. 
for direct measurement of ash and moisture content and calculation of the calorific value of coal in redundant, averaged and crushed material, returned to the main conveyor belt after each sampling by the sampler.

Technical specifications:

- Coal type: hard,

- Granulation of carbon: issued by the sampler crusher,

- Volume of the measuring chamber: $5 \mathrm{~L}$,

- Measuring method of ash content: dispersion of gamma radiation,

- Radiation source: Am-241 with activity 3.7 GBq.

WILPO CG 111-isotope density meter is designed for on-line determination of density of liquids or slurries transported in industrial pipelines, especially in ash slurries. Density meter is practically maintenance-free device, mounted directly on the pipelines transporting the slurries. The measuring system consists of controller unit, which can work autonomously or work together with an external PC unit as well as consist of the isotope head and detection unit.

Technical specifications:

- Measured material: slurries, liquids,

- Method of measurement: absorption of gamma radiation,

- Radiation source: Cs-137.

The on-line coal quality monitors and users are shown in Table 3 and Table 4.

Table 3. Installations-on-line coal quality monitors by WILPO [23].

\begin{tabular}{|c|c|c|c|}
\hline USERS & & ADDRESS & TYPE OF DEVICE \\
\hline "BEŁCHATÓW" & Coal Mine & $\begin{array}{l}97 \text { - } 400 \text { Bełchatów, } \\
\text { skr. pocztowa } 100\end{array}$ & $\begin{array}{l}\text { C } 212 \text { (5 pieces }) \\
\text { C } 512 \text { (4 pieces) }\end{array}$ \\
\hline “BOBREK” & Coal Mine & 41 - 905 Bytom, ul. Konstytucji 76 & $\begin{array}{l}\text { C } 431 \text { (2 pieces) } \\
\text { C } 112 \mathrm{~A}, \mathrm{C} 212\end{array}$ \\
\hline “CENTRUM" & Coal Mine & 41 - 902 Bytom, ul. Łużycka 7 & C 132 \\
\hline “BOLESŁAW ŚMIAŁY” & Coal Mine & $\begin{array}{c}43-174 \\
\text { Łaziska G, } \\
\text { ul. Pstrowskiego } 12\end{array}$ & $\begin{array}{l}\text { C 411A, C 431, } \\
532 \mathrm{hc} \text { (3 pieces) }\end{array}$ \\
\hline “BRZESZCZE” & Coal Mine & $\begin{array}{c}43 \text { - } 270 \text { Brzeszcze, } \\
\text { ul. Kościuszki } 1\end{array}$ & $\begin{array}{l}\text { C } 132, \text { C } 212 \\
(3 \text { pieces })\end{array}$ \\
\hline "BUDRYK" & Coal Mine & $\begin{array}{c}43 \text { - } 178 \\
\text { Onontowice, } \\
\text { ul. Zamkowa } 10\end{array}$ & $\begin{array}{l}\text { C } 411 \mathrm{~A} \text { (2 pieces), } \\
\text { C 132, C 212, } \\
\text { C 532hc ( } 3 \text { pieces) }\end{array}$ \\
\hline “CHWAŁOWICE” & Coal Mine & $\begin{array}{c}44 \text { - } 206 \text { Rybnik 6, } \\
\text { ul. } 1 \text { Maja } 26\end{array}$ & $\begin{array}{l}\text { C } 411 \mathrm{~A} \text { ( } 3 \text { pieces }) \\
\text { C } 532 \mathrm{hc}(2 \text { pieces })\end{array}$ \\
\hline $\begin{array}{l}\text { "HALEMBA-WIREK" } \\
\text { Ruch Halemba }\end{array}$ & Coal Mine & 41 - 706 Ruda Śląska, ul. Kłodnicka 54 & $\mathrm{C} 411 \mathrm{~A}$ \\
\hline "JANINA" & Coal Mine & $\begin{array}{l}32 \text { - } 590 \text { Libiąż, } \\
\text { ul. Górnicza } 23\end{array}$ & C $532 \mathrm{hc}$ \\
\hline "JANKOWICE" & Coal Mine & $\begin{array}{l}44 \text { - } 253 \text { Rybnik, } \\
\text { ul. Jastrzębska } 12\end{array}$ & $\begin{array}{c}\text { C } 132 \text { (3 pieces), } \\
\text { C 411A, C } 532 \text { hc (2 pieces) }\end{array}$ \\
\hline “KRUPIŃSKI” & Coal Mine & $\begin{array}{l}43 \text { - } 267 \text { Suszec, } \\
\text { ul. Piaskowa } 35\end{array}$ & C $532 \mathrm{hc}$ ( 3 pieces) \\
\hline
\end{tabular}




\section{Continued}

\begin{tabular}{|c|c|c|c|}
\hline “KAZIMIERZ JULIUSZ” & Coal Mine & $\begin{array}{l}42 \text { - } 540 \text { Sosnowiec, } \\
\text { ul. Ogrodowa } 1\end{array}$ & C 431 \\
\hline $\begin{array}{c}\text { “KNURÓW-SZCZYGLOWICE” } \\
\text { Ruch Knurów }\end{array}$ & Coal Mine & $\begin{array}{l}42 \text { - } 220 \text { Knurów, } \\
\text { ul. Dworcowa } 1\end{array}$ & C $411 \mathrm{~A}, \mathrm{C} 213$ \\
\hline $\begin{array}{c}\text { "KNURÓW-SZCZYGŁOWICE” } \\
\text { Ruch Szczygłowice }\end{array}$ & Coal Mine & $\begin{array}{l}44 \text { - } 193 \text { Knurów 3, } \\
\text { ul. Górnicza } 1\end{array}$ & C 411A, C 431 (4 pieces) \\
\hline “KONIN” & Coal Mine & $\begin{array}{l}62 \text { - } 540 \text { Kleczew, } \\
\text { ul. } 600 \text {-lecia } 9\end{array}$ & $\begin{array}{c}\text { C } 212 \text { (3 pieces) } \\
\text { C } 512\end{array}$ \\
\hline "SOŚNICA" & Coal Mine & $\begin{array}{l}44 \text { - } 103 \text { Gliwice, } \\
\text { ul. Błonie } 6\end{array}$ & $\begin{array}{c}\text { C 213, C 411A, } \\
\text { C } 431 \text { (2 pieces), } \\
\text { C } 532 \mathrm{hc} \text { (2 pieces) }\end{array}$ \\
\hline “MAKOSZOWY” & Coal Mine & $\begin{array}{c}41 \text { - } 800 \text { Zabrze, } \\
\text { ul. Makoszowska } 24\end{array}$ & $\begin{array}{c}\text { C } 132, \text { C } 431, \text { C } 212, \\
\text { C } 532 \mathrm{hc}\end{array}$ \\
\hline "MARCEL" & Coal Mine & $\begin{array}{l}44 \text { - } 310 \text { Radlin, } \\
\text { ul. Korfantego } 52\end{array}$ & $\begin{array}{c}\text { C 411A (2 pieces), } \\
\text { C 132, C } 732 \text { (2 pieces) }\end{array}$ \\
\hline $\begin{array}{l}\text { "MARPO" } \\
\text { (BB POL) }\end{array}$ & Sp.j & 70 - 675 Szczecin, Grudzińskiego 12 & C $532 \mathrm{hc}$ \\
\hline "MYSŁOWICE-WESOŁA" & Coal Mine & $\begin{array}{l}41 \text { - } 408 \text { Mysłowice, } \\
\text { ul. Kopalniana } 5\end{array}$ & $\begin{array}{c}\text { C } 132 \\
\text { C } 532 \mathrm{hc}\end{array}$ \\
\hline "PIAST" Ruch II & Coal Mine & $\begin{array}{l}43 \text { - } 225 \text { Wola, } \\
\text { ul. Kopalniana } 10\end{array}$ & C 132 (4 pieces) \\
\hline "PIEKARY" & Coal Mine & $\begin{array}{l}41 \text { - } 949 \text { Piekary } \\
\text { Śląskie, } \\
\text { ul. Brzechwy } 13\end{array}$ & C 132, C 431 (3 pieces) \\
\hline “PNIÓWEK" & Coal Mine & 43 - 251 Pawłowice Śl., ul. Krucza 18 & C $532 \mathrm{hc}$ (2 pieces) \\
\hline "RADLIN" & Coking plant & $\begin{array}{l}44 \text { - } 310 \text { Radlin, } \\
\text { ul. Hutnicza } 1\end{array}$ & C 132 \\
\hline $\begin{array}{l}\text { "RYDUŁTOWY-ANNA" } \\
\text { Ruch I-Rydułtowy }\end{array}$ & Coal Mine & $\begin{array}{l}44 \text { - } 280 \text { Rydułtowy, } \\
\text { ul. Leona } 2\end{array}$ & $\mathrm{C} 411 \mathrm{~A}$ \\
\hline "SILESIA" & Coal Mine & 43 - 502 Czechowice Dz., ul. Górnicza 60 & C 132 \\
\hline $\begin{array}{l}\text { "MURCKI-STASZIC" } \\
\text { Ruch Staszic }\end{array}$ & Coal Mine & $\begin{array}{c}40-167 \\
\text { Katowice, } \\
\text { ul. Karolinki } 1\end{array}$ & C $112 \mathrm{~A}$ (2 pieces) \\
\hline “TURÓW” & Coal Mine & $\begin{array}{c}59-916 \\
\text { Bogatynia } 3\end{array}$ & C 612 \\
\hline “TURÓW” & $\begin{array}{l}\text { Power } \\
\text { station }\end{array}$ & $\begin{array}{c}\text { ul. Młodych } \\
\text { Energetyków } 12 \\
59-916 \\
\text { Bogatynia } 3\end{array}$ & $\begin{array}{l}\text { C } 212 \text { ( } 2 \text { pieces }) \text {, } \\
\text { C } 512 \text { ( } 4 \text { pieces) }\end{array}$ \\
\hline "WIECZOREK" & Coal Mine & $\begin{array}{c}40-432 \\
\text { Katowice, } \\
\text { ul. Szopienicka } 58\end{array}$ & C 212 \\
\hline “WUJEK" Ruch Wujek & Coal Mine & $\begin{array}{c}40 \text { - } 598 \\
\text { Katowice, } \\
\text { ul. W. Pola } 65\end{array}$ & C 132, C $532 \mathrm{hc}$ \\
\hline $\begin{array}{l}\text { "WUJEK" } \\
\text { Ruch Śląsk }\end{array}$ & Coal Mine & $\begin{array}{l}41 \text { - } 707 \text { Ruda Śląska, } \\
\text { ul. Kalinowa } 12\end{array}$ & $\begin{array}{c}\text { C 132, C } 212, \text { C } 411 \mathrm{~A}, \\
\text { C } 431\end{array}$ \\
\hline
\end{tabular}




\section{Continued}

\begin{tabular}{|c|c|c|c|}
\hline “ZIEMOWIT” & Coal Mine & 43 - 143 Lędziny, ul. Pokoju 4 & $\begin{array}{l}\text { C } 132, \text { C } 431 \\
(2 \text { pieces }) \\
\text { C } 532 \mathrm{hc}\end{array}$ \\
\hline “SOBIESKI" & Coal Mine & $\begin{array}{c}43-600 \\
\text { Jaworzno, ul. } \\
\text { Grunwaldzka } 37\end{array}$ & C $532 \mathrm{hc}$ \\
\hline ZE PAK & S.A. & $\begin{array}{l}52 \text { - } 510 \text { Konin, } \\
\text { ul. Kazimierska } 45\end{array}$ & C 512 \\
\hline USERS & & ADDRESS & TYPE OF DEVICE \\
\hline "BEŁCHATÓW" & Coal Mine & $\begin{array}{l}97 \text { - } 400 \text { Bełchatów, } \\
\text { skr. pocztowa } 100\end{array}$ & $\begin{array}{l}\text { C } 212 \text { (5 pieces) } \\
\text { C } 512 \text { (4 pieces) }\end{array}$ \\
\hline "BOBREK" & Coal Mine & $\begin{array}{l}41 \text { - } 905 \text { Bytom, } \\
\text { ul. Konstytucji } 76\end{array}$ & $\begin{array}{l}\text { C } 431 \text { (2 pieces), } \\
\text { C } 112 \mathrm{~A}, \text { C } 212\end{array}$ \\
\hline “CENTRUM” & Coal Mine & $\begin{array}{l}41 \text { - } 902 \text { Bytom, } \\
\text { ul. Łużycka } 7\end{array}$ & C 132 \\
\hline "BOLESŁAW ŚMIAŁY” & Coal Mine & $\begin{array}{c}43-174 \\
\text { Łaziska G, } \\
\text { ul. Pstrowskiego } 12\end{array}$ & $\begin{array}{l}\text { C 411A, C 431, } \\
532 \mathrm{hc} \text { (3 pieces) }\end{array}$ \\
\hline “BRZESZCZE” & Coal Mine & $\begin{array}{l}43 \text { - } 270 \text { Brzeszcze, } \\
\text { ul. Kościuszki } 1\end{array}$ & $\begin{array}{l}\text { C } 132, \text { C } 212 \\
\text { (3 pieces) }\end{array}$ \\
\hline "BUDRYK" & Coal Mine & $\begin{array}{c}43 \text { - } 178 \\
\text { Onontowice, } \\
\text { ul. Zamkowa } 10\end{array}$ & $\begin{array}{l}\text { C 411A (2 pieces), } \\
\text { C 132, C 212, } \\
\text { C 532hc ( } 3 \text { pieces) }\end{array}$ \\
\hline “CHWAŁOWICE” & Coal Mine & $\begin{array}{l}44 \text { - } 206 \text { Rybnik 6, } \\
\text { ul. } 1 \text { Maja } 26\end{array}$ & $\begin{array}{l}\text { C } 411 \mathrm{~A} \text { ( } 3 \text { pieces }) \\
\text { C } 532 \mathrm{hc}(2 \text { pieces })\end{array}$ \\
\hline $\begin{array}{l}\text { "HALEMBA-WIREK" } \\
\text { Ruch Halemba }\end{array}$ & Coal Mine & 41 - 706 Ruda Śląska, ul. Kłodnicka 54 & $\mathrm{C} 411 \mathrm{~A}$ \\
\hline “JANINA" & Coal Mine & $\begin{array}{l}32 \text { - } 590 \text { Libiąż, } \\
\text { ul. Górnicza } 23\end{array}$ & C 532hc \\
\hline "JANKOWICE" & Coal Mine & $\begin{array}{l}44 \text { - } 253 \text { Rybnik, } \\
\text { ul. Jastrzębska } 12\end{array}$ & $\begin{array}{l}\text { C } 132 \text { (3 pieces), } \\
\text { C } 411 \mathrm{~A}, \mathrm{C} 532 \mathrm{hc} \\
\text { (2 pieces })\end{array}$ \\
\hline “KRUPIŃSKI” & Coal Mine & $\begin{array}{l}43 \text { - } 267 \text { Suszec, } \\
\text { ul. Piaskowa } 35\end{array}$ & C $532 \mathrm{hc}$ (3 pieces) \\
\hline “KAZIMIERZ JULIUSZ” & Coal Mine & $\begin{array}{l}42 \text { - } 540 \text { Sosnowiec, } \\
\text { ul. Ogrodowa } 1\end{array}$ & C 431 \\
\hline $\begin{array}{c}\text { "KNURÓW-SZCZYGŁOWICE" } \\
\text { Ruch Knurów }\end{array}$ & Coal Mine & $\begin{array}{l}42 \text { - } 220 \text { Knurów, } \\
\text { ul. Dworcowa } 1\end{array}$ & C 411A, C 213 \\
\hline $\begin{array}{l}\text { "KNURÓW-SZCZYGŁOWICE” } \\
\text { Ruch Szczygłowice }\end{array}$ & Coal Mine & $\begin{array}{l}44 \text { - } 193 \text { Knurów 3, } \\
\text { ul. Górnicza } 1\end{array}$ & C 411A, C 431 (4 pieces) \\
\hline “KONIN” & Coal Mine & $\begin{array}{l}62-540 \text { Kleczew, } \\
\text { ul. } 600 \text {-lecia } 9\end{array}$ & $\begin{array}{l}\text { C } 212 \text { ( } 3 \text { pieces) } \\
\text { C } 512\end{array}$ \\
\hline "SOŚNICA" & Coal Mine & $\begin{array}{l}44 \text { - } 103 \text { Gliwice, } \\
\text { ul. Błonie } 6\end{array}$ & $\begin{array}{l}\text { C 213, C 411A, } \\
\text { C } 431 \text { (2 pieces), } \\
\text { C } 532 \mathrm{hc} \text { ( } 2 \text { pieces })\end{array}$ \\
\hline "MAKOSZOWY" & Coal Mine & $\begin{array}{l}41 \text { - } 800 \text { Zabrze, } \\
\text { ul. Makoszowska } 24\end{array}$ & $\begin{array}{c}\text { C } 132, \text { C } 431, \text { C } 212, \\
\text { C } 532 \mathrm{hc}\end{array}$ \\
\hline
\end{tabular}




\begin{tabular}{|c|c|c|c|}
\hline "MARCEL" & Coal Mine & $\begin{array}{l}44 \text { - } 310 \text { Radlin, } \\
\text { ul. Korfantego } 52\end{array}$ & $\begin{array}{l}\text { C 411A (2 pieces), } \\
\text { C 132, C } 732 \text { (2 pieces) }\end{array}$ \\
\hline $\begin{array}{l}\text { “MARPO” } \\
\text { (BB POL) }\end{array}$ & Sp.j & 70 - 675 Szczecin, Grudzińskiego 12 & C $532 \mathrm{hc}$ \\
\hline “MYSŁOWICE-WESOŁA" & Coal Mine & $\begin{array}{l}41 \text { - } 408 \text { Mysłowice, } \\
\text { ul. Kopalniana } 5\end{array}$ & $\begin{array}{l}\text { C } 132 \\
\text { C } 532 \mathrm{hc}\end{array}$ \\
\hline “PIAST" Ruch II & Coal Mine & $\begin{array}{l}43 \text { - } 225 \text { Wola, } \\
\text { ul. Kopalniana } 10\end{array}$ & C 132 (4 pieces) \\
\hline "PIEKARY" & Coal Mine & $\begin{array}{c}41 \text { - } 949 \text { Piekary Śląskie, } \\
\text { ul. Brzechwy } 13\end{array}$ & C 132, C 431 (3 pieces) \\
\hline "PNIÓWEK" & Coal Mine & $\begin{array}{c}43 \text { - } 251 \text { Pawłowice } \\
\text { Śl., ul. Krucza } 18\end{array}$ & C $532 \mathrm{hc}$ (2 pieces) \\
\hline “RADLIN" & Coking plant & $\begin{array}{l}44 \text { - } 310 \text { Radlin, } \\
\text { ul. Hutnicza } 1\end{array}$ & C 132 \\
\hline $\begin{array}{c}\text { "RYDUŁTOWY-ANNA" } \\
\text { Ruch I-Rydułtowy }\end{array}$ & Coal Mine & $\begin{array}{l}44 \text { - } 280 \text { Rydułtowy, } \\
\text { ul. Leona } 2\end{array}$ & C $411 \mathrm{~A}$ \\
\hline “SILESIA" & Coal Mine & 43 - 502 Czechowice Dz., ul. Górnicza 60 & C 132 \\
\hline $\begin{array}{l}\text { "MURCKI- } \\
\text {-STASZIC" } \\
\text { Ruch Staszic }\end{array}$ & Coal Mine & $\begin{array}{c}40-167 \\
\text { Katowice, } \\
\text { ul. Karolinki } 1\end{array}$ & C $112 \mathrm{~A}$ (2 pieces) \\
\hline “TURÓW” & Coal Mine & $\begin{array}{c}59-916 \\
\text { Bogatynia } 3\end{array}$ & C 612 \\
\hline “TURÓW” & $\begin{array}{l}\text { Power } \\
\text { station }\end{array}$ & $\begin{array}{c}\text { ul. Młodych } \\
\text { Energetyków } 12 \\
59-916 \\
\text { Bogatynia } 3\end{array}$ & $\begin{array}{l}\text { C } 212 \text { (2 pieces), } \\
\text { C } 512 \text { (4 pieces) }\end{array}$ \\
\hline "WIECZOREK" & Coal Mine & $\begin{array}{c}40-432 \\
\text { Katowice, } \\
\text { ul. Szopienicka } 58\end{array}$ & C 212 \\
\hline "WUJEK" Ruch Wujek & Coal Mine & $\begin{array}{c}40-598 \\
\text { Katowice, } \\
\text { ul. W. Pola } 65\end{array}$ & C 132, C 532hc \\
\hline $\begin{array}{l}\text { "WUJEK" } \\
\text { Ruch Śląsk }\end{array}$ & Coal Mine & $\begin{array}{l}41 \text { - } 707 \text { Ruda Śląska, } \\
\text { ul. Kalinowa } 12\end{array}$ & $\begin{array}{c}\text { C 132, C } 212, \text { C } 411 \mathrm{~A}, \\
\text { C } 431\end{array}$ \\
\hline "ZIEMOWIT" & Coal Mine & 43 - 143 Lędziny, ul. Pokoju 4 & $\begin{array}{c}\text { C 132, C } 431 \text { (2 pieces), } \\
\text { C } 532 \mathrm{hc}\end{array}$ \\
\hline “SOBIESKI” & Coal Mine & $\begin{array}{c}43-600 \\
\text { Jaworzno, } \\
\text { ul. Grunwaldzka } 37\end{array}$ & C $532 \mathrm{hc}$ \\
\hline ZE PAK & S.A. & $\begin{array}{l}52 \text { - } 510 \text { Konin, } \\
\text { ul. Kazimierska } 45\end{array}$ & C 512 \\
\hline
\end{tabular}

Table 4. Installations-Export by WILPO [23].

\begin{tabular}{|c|c|c|c|}
\hline \multicolumn{2}{|c|}{ USERS } & ADDRESS & TYPE OF DEVICE \\
\hline "CORESTI" & Plant & Petrosani, ROMANIA & WILPO C 212 \\
\hline "CORESTI" & Plant & Petrosani, ROMANIA & WILPO C 431 \\
\hline KOSTOLAC & Power Station & Pożarevac, SERBIA & WILPO C 212 \\
\hline
\end{tabular}


According to data from 2009, in national mining works about 100 on-line radiometric ash meters from various companies, based on transmission and backscattering methods of gamma radiation, including over 60 WILPO solutions. There are currently 10 continuous ash meters in the Polish brown coal mining industry, all production of "WILPO" Sp. z o.o. (WILPO C 212 sub-belt ash meters).

\section{5. "SYSKON—Systemy Kontroli Procesów Przemysłowych" Henryk Zastawny [24]}

Kościerzyńska 7, 51 - 416 Wrocław, http://www.syskon.eu.

Company operating since 1995. Designs, creates and implements systems for continuous measurement of coal quality on belt conveyors and testing the content of flammable particles in flue gas.

The radiation level on the surface of the source container is well below the level allowed by the PAA regulations, i.e. $2 \mathrm{mSv} / \mathrm{h}$. Measurements are made automatically and no employee is required near the device.

SysKon 50 -is a control device that allows on-line measure the density of fluids, pulp, mules, etc. transported in pipelines (Figure 16).

The measurement principle is based on the determination of the high energy gamma radiation absorption by the material under study. The gauge is installed directly on the ascending section of the pipeline, which guarantees that the pipe cross-section is filled with the tested material.

Technical specifications:

- pipeline width: unlimited,

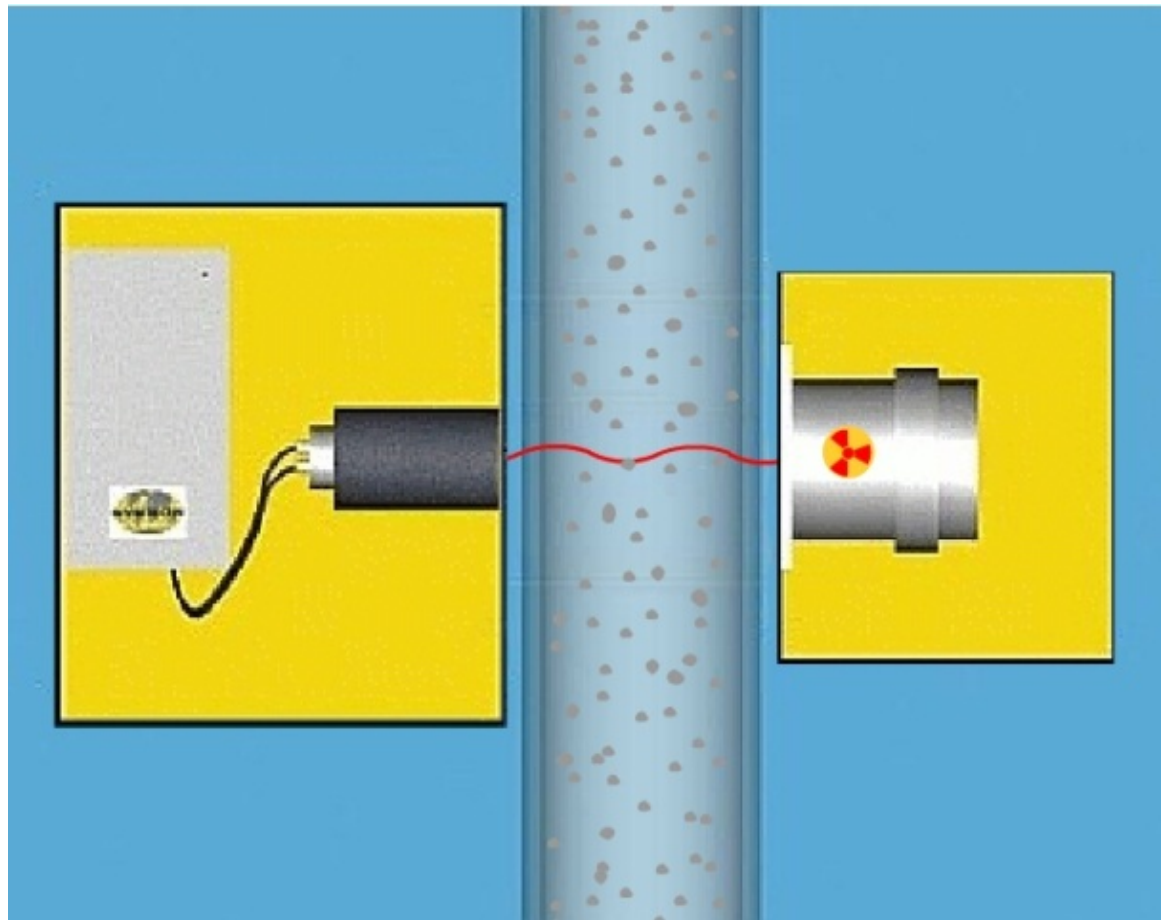

Figure 16. SysKon50 [24]. 
- liquid flow speed: unlimited,

- transport performance: unlimited,

- maximum granulation: unlimited,

- density range: unlimited,

- measurement time: about $1 \mathrm{~min}$,

- radiation source: Cs-137.

SysKon 202-a control device that measures a content of flammable parts in fly ash. The probe is installed in the flue gas duct, using the negative pressure prevailing there, continuously samples the ash. The sample weighing about $10 \mathrm{~g}$ is directed to the measuring container, where it is scanned with gamma radiation, while its dielectric parameters are measured. From the relation between the absorption of gamma radiation and dielectric properties, the content of flammable parts is calculated. After measurement, the sample is expelled back into the flue gas duct and a new cycle begins.

Technical specifications:

- range of flammable parts: $0 \%-16 \%$,

- measurement time: 3 - 5 min,

- radiation sources: Cs-137.

SysKonSystem (Figure 17) and SysKonSystemSkan (Figure 18)-a devices controlling the quality of coal transported by a belt conveyor (ash content, moisture, calculation of calorific value). The device measures the coal in the middle of the conveyor belt-this is the main feature that differs from the SysKonSystem-Skan. The Skan version of device, in the case of a non-uniform stream of material on the conveyor, thanks to the lateral scanning of this stream, better averages the measured values-this is the main feature that differs from

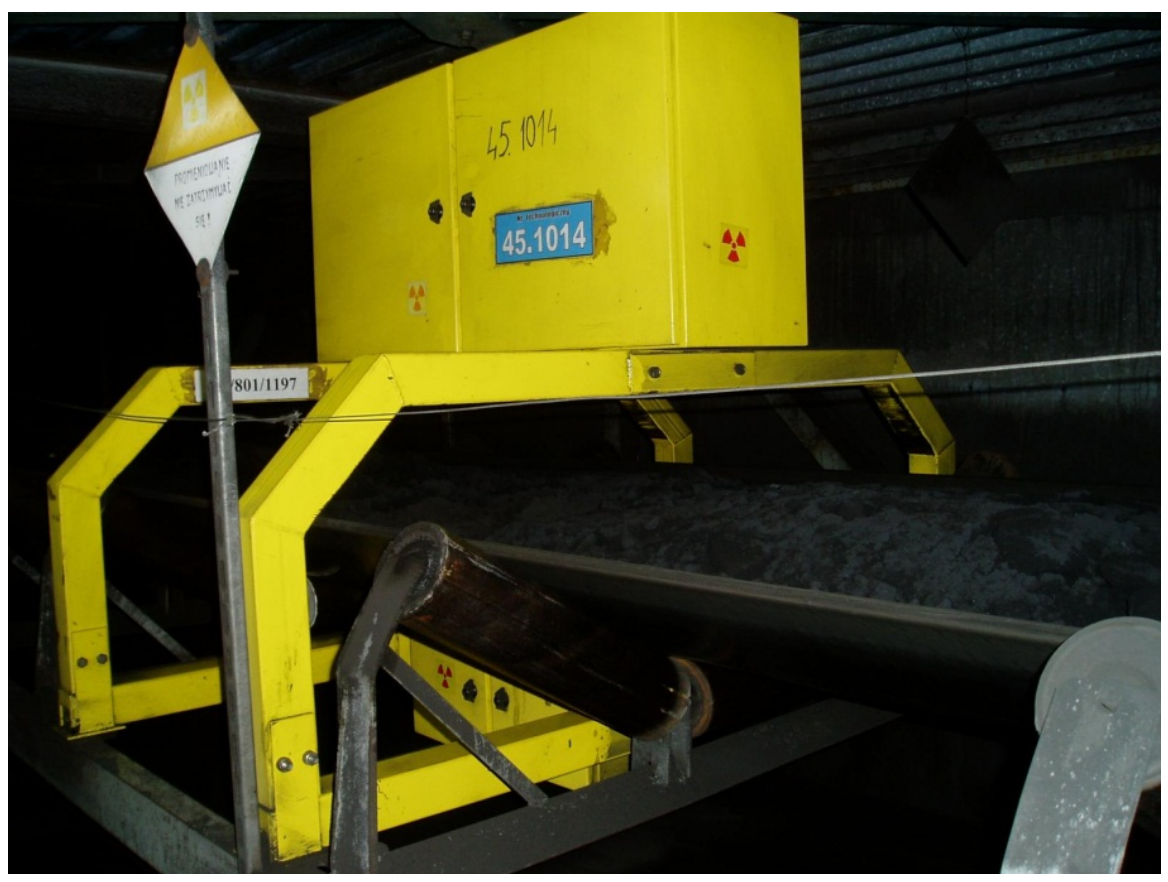

Figure 17. SysKonSystem in Lubelski Węgiel "BOGDANKA” [24]. 
the SysKonSystem device.

Technical specifications:

- type of coal: hard,

- granulation: 0-300 mm,

- layer height: $50-300 \mathrm{~mm}$,

- radiation sources: Am-241, Cs-137.

SysKon400-a device with nucleonic weighers that controls the quality of coal transported by a belt conveyor (ash and moisture content, mass of coal). The device is optionally mounted with an additionally technological scale. The device is adapted for use in underground mining plants in methane explosive areas (Figure 19).

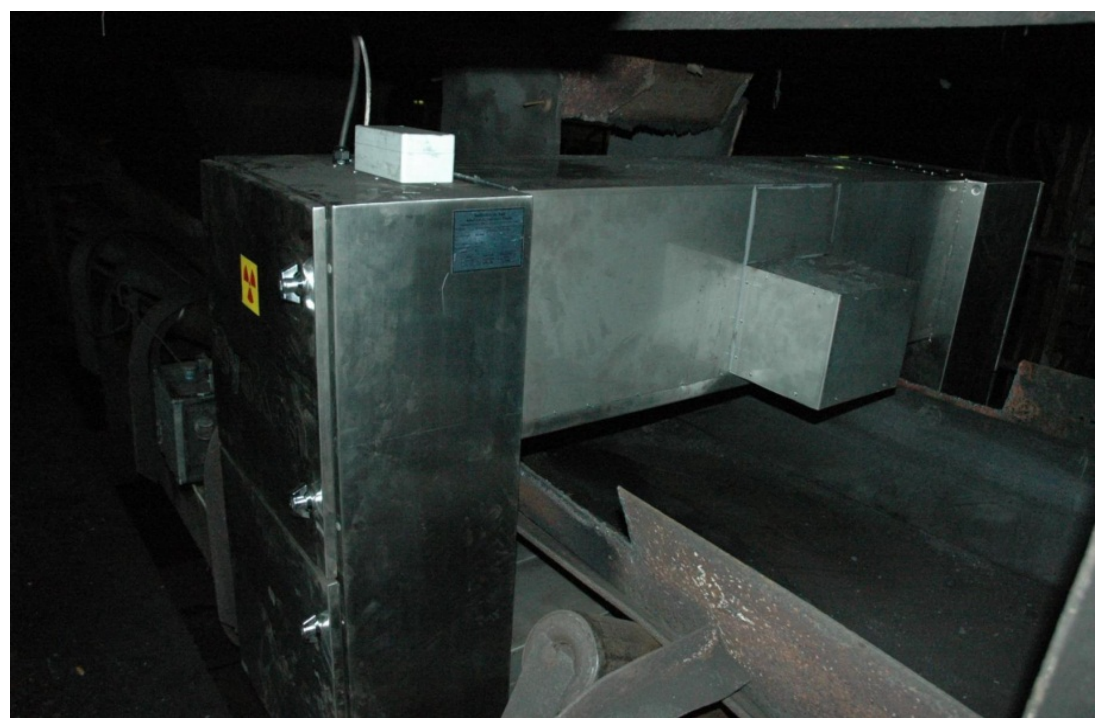

Figure 18. SysKonSystem-Skan in "Brzeszcze" Coal Mine [24].

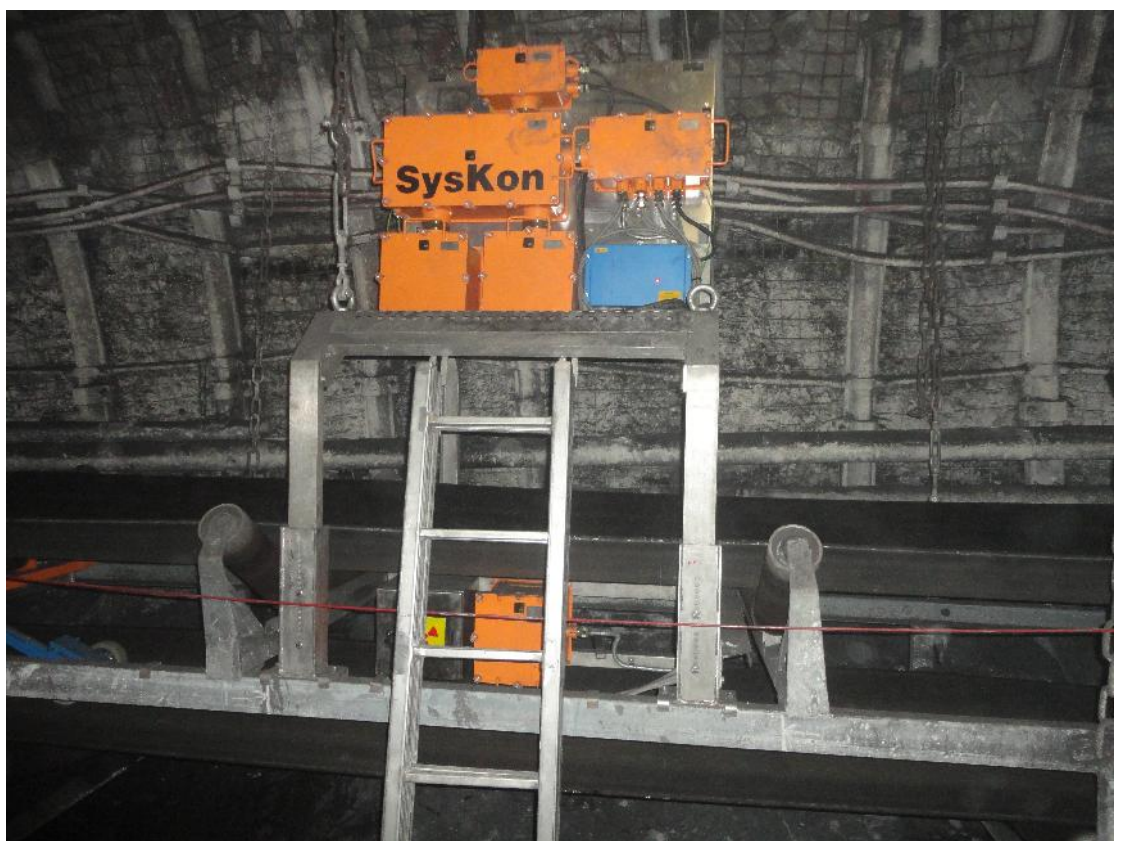

Figure 19. SysKon400 in Lubelski Węgiel "BOGDANKA" [24]. 
Technical specifications:

- type of coal: hard,

- granulation: 0 - $300 \mathrm{~mm}$,

- layer height: 50 - $300 \mathrm{~mm}$,

- radiation sources: Am-241, Cs-137.

SysKon500-the device that controls the quality of coal transported by a belt conveyor (Figure 20). The measurement of coal is carried out using the activation method. Individual elements included in coal, under the influence of neutron with energies of $1-10 \mathrm{MeV}$ they generate a characteristic energy spectrum. Through his examination it can be determined the content of coal, ash, moisture and calorific value of the examined coal.

The device allows to determine the content of elements such as: carbon, hydrogen, oxygen, calcium, chlorine, silicon, sulfur, iron and aluminum. The design of the analyzer is built-up around a conveyor belt. Under the carrier tape, in the bottom tunnel of the device, an isotopic neutron source is placed (Am-Be). Over the tape, in the upper tunnel devices, detectors are placed gamma radiation. The design contains system of protective covers against neutron and gamma radiation.

Technical specifications:

- type of coal: hard,

- granulation: 0 - $300 \mathrm{~mm}$,

- layer height: from $100 \mathrm{~mm}$,

- neutron source: Am-Be.

Installed de4vices and users are shown in Table 5.

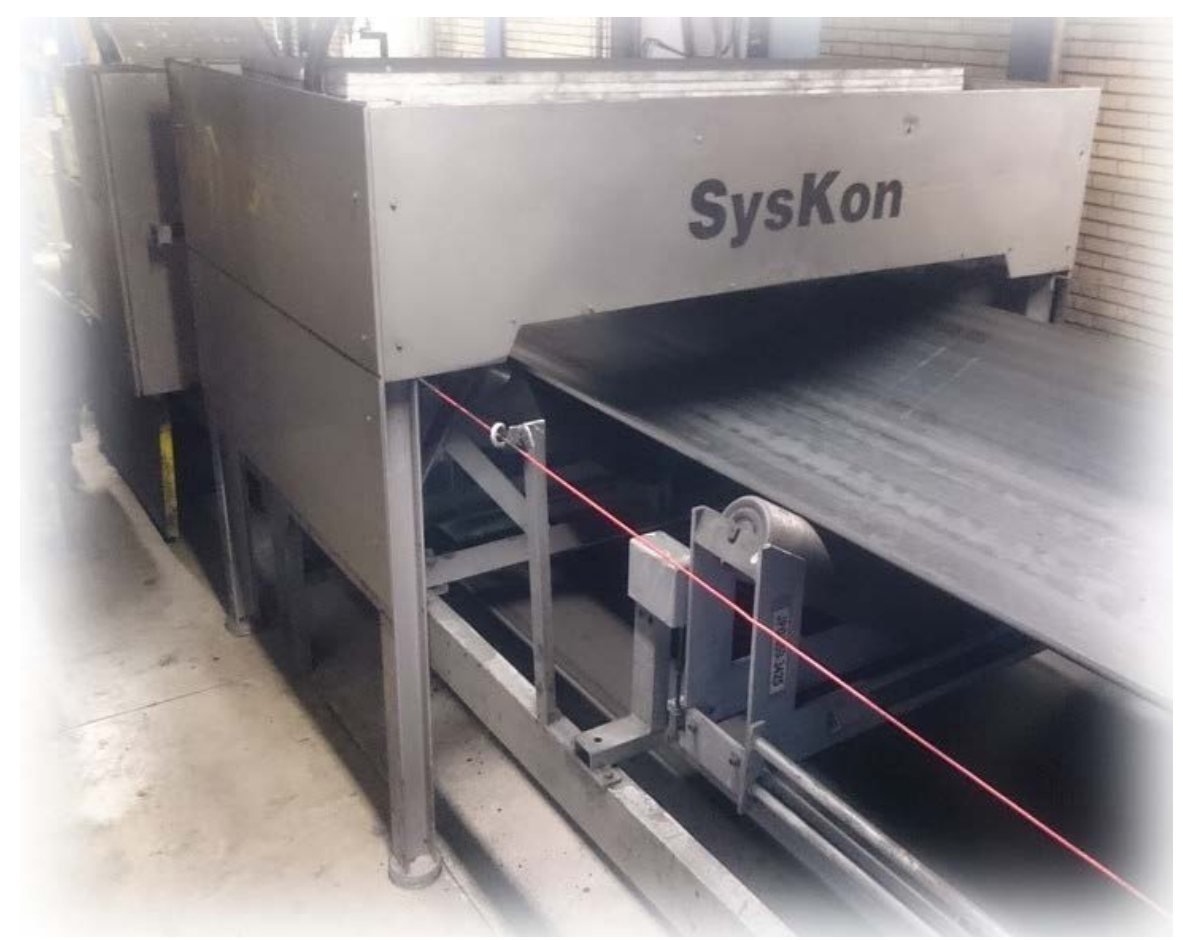

Figure 20. SysKon500 [24]. 
Table 5. Installed devices by SYSKON [24].

\begin{tabular}{|c|c|c|}
\hline USERS & LOCATION & TYPE OF DEVICE \\
\hline "Łęczyńska Energetyka" & Bogdanka & SysKonSystem: 1 \\
\hline Lubelski Węgiel "BOGDANKA" & Bogdanka & $\begin{array}{c}\text { SysKonSystem: } 3 \\
\text { SysKonSystemSkan: } 7 \\
\text { SysKonSystemLab: } 1 \\
\text { SysKon 400: } 5\end{array}$ \\
\hline Przedsiębiorstwo Górnicze "SILESIA" & $\begin{array}{l}\text { Czechowice-Dziedzi } \\
\text { ce }\end{array}$ & $\begin{array}{c}\text { SysKonSystem: } 2 \\
\text { SysKonSystemSkan: } 2\end{array}$ \\
\hline Zakład Górniczy “Sobieski” & Jaworzno & SysKonSystem: 1 \\
\hline Kopalnia Węgla Kamiennego "Mysłowice-Wesoła" & Mysłowice & SysKonSystem: 2 \\
\hline Kopalnia Węgla Kamiennego "Brzeszcze" & Brzeszcze & SysKonSystemSkan: 3 \\
\hline ENEA Wytwarzanie S.A. & Kozienice & SysKon 202: 8 \\
\hline $\begin{array}{l}\text { PGE Górnictwo i Energetyka Konwencjonalna } \\
\text { Spółka Akcyjna, Elektrownia Dolna Odra }\end{array}$ & Nowe Czarnowo & SysKon 202: 6 \\
\hline $\begin{array}{l}\text { Zespół Elektrociepłowni Wrocławskich } \\
\text { KOGENERACJA S.A. }\end{array}$ & Wrocław & SysKon 202: 6 \\
\hline PGE Energia Ciepła S.A. & Rybnik & SysKon 202: 4 \\
\hline Ostravská těžební, a.s. & $\begin{array}{l}\text { Śląska Ostrawa } \\
\text { (Czech Republic) }\end{array}$ & SysKonSystem: 2 \\
\hline
\end{tabular}

\subsection{TD-ELECTRONICS Tomasz Dudek [25]}

Blatona 1/63, 01-494 Warszawa, http://www.td-electronics.pl.

Exists since 1998 and specializes in software development, construction and implementation of electronic, isotope, measuring equipment for industry, laboratories and environmental measurements.

Isotope measurements are carried out by means of the TDI series. These are meters containing a radioactive source and an ionizing radiation detector. It is possible to measure (where xx can be Am-241, Cs-137, Co-60, Kr-85, Cd-109, Pm-147, Sr-90):

TDI-xx-GT-Traversing thickness or basis weight (Figure 21) is intended for continuous, non-contact measurement of the thickness profile of film, paper, and sheets (depending on the radiation source used). It uses the absorption method of measurement. The radioactive source is placed under while the detector assembly over the measured of material tape. The traverse mechanism (scanner) enables synchronous movement of the source-head system, across the produced tape, between the parametrically determined turning points.

TDI-xx-GR-Stationary thicknesses or basis weight is designed for continuous, non-contact measurement of thickness or basic weight of film, paper, sheets, and plates (depending on the radiation source used) directly on the production line. It uses the absorption method of measurement.

The measuring head system (source-detector) of the thickness or basis weight 


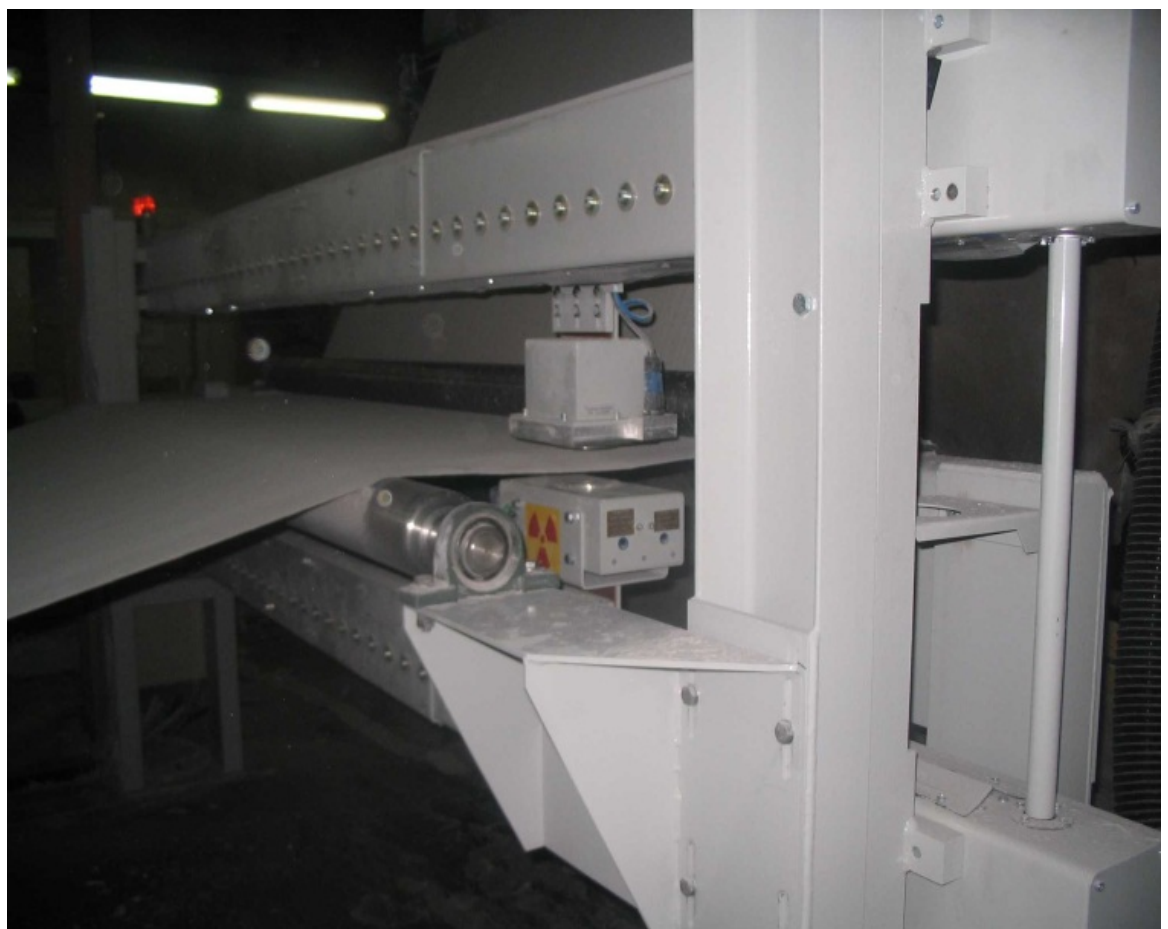

Figure 21. Traversing thickness gauge [25].

gauge is installed on a fixed structure and measures along the band of measured material moving between the source and the detector. On one production line, it is possible to install one or several measuring heads. Depending on the thickness and type of band material being measured and the required metrological parameters of the gauge, the appropriate radiation source, its activity, the protective container and the type of detector are selected.

TDI-xx-GE-Density or concentration in the pipe is intended for continuous, non-contact density measurement and derivative parameters of liquids, solutions and suspensions in pipelines. For the measurement, an attenuated gamma radiation by medium variable density or concentration is used.

Technical parameters:

- measurement range: $0.4-5.0 \mathrm{~g} / \mathrm{cm}^{3}$,

- outer diameter of steel pipes: $100-500 \mathrm{~mm}$,

- outer diameter of PVC pipes: 40 - $90 \mathrm{~mm}$,

- radiation sources: Am-241 (0.5 - 4 GBq) or Cs-137 (0.5 - 15 GBq).

TDI-xx-GZ-Density and concentrations in the tank.

Gauges are designed to measure the density or concentration of liquid media and suspensions in tanks. They use the absorption method of measurement. The measurement head of the densitometer or concentration meter is made up of a system of source and radiation detector assemblies installed on a suitable mechanical construction. Measured medium must completely fill the space between the source and detector assembly in the tank. Depending on the thickness of the tank wall, the distance between the source and the detector, the type and density of the medium being measured and the meter's required metrological parame- 
ters, the appropriate radiation source, its activity, protective container and type of detector are selected.

TDI-xx-OG-Thickness, density and concentration (Figure 22).

These meters use a scattering method for their work. They are utilized primarily where it is not possible to use the absorption method, because (e.g. due to technological reasons) access to the measuring medium is possible only on one side.

TDI-xx-WA-Mass on conveyors (Figure 23).

Nucleonic weigher's belt conveyors are meters intended for measuring the mass of loose media transported by conveyor belts. They use the absorption method of measurement. The measuring head is a fixed frame located across the moving conveyor belt. On the frame above the conveyor there are installed sources (source) of radiation in a suitable container. A linear detector is installed under the conveyor belt. Depending on the width of the conveyor belt and the amount and type of material on the belt, the appropriate radiation source, its activity, protective container and the type of detector are selected.

TDI-xx-PL-Level (linear) and TDI-xx-PP-Level (point).

Isotopic level gauges used for linear measurement of media levels in a given

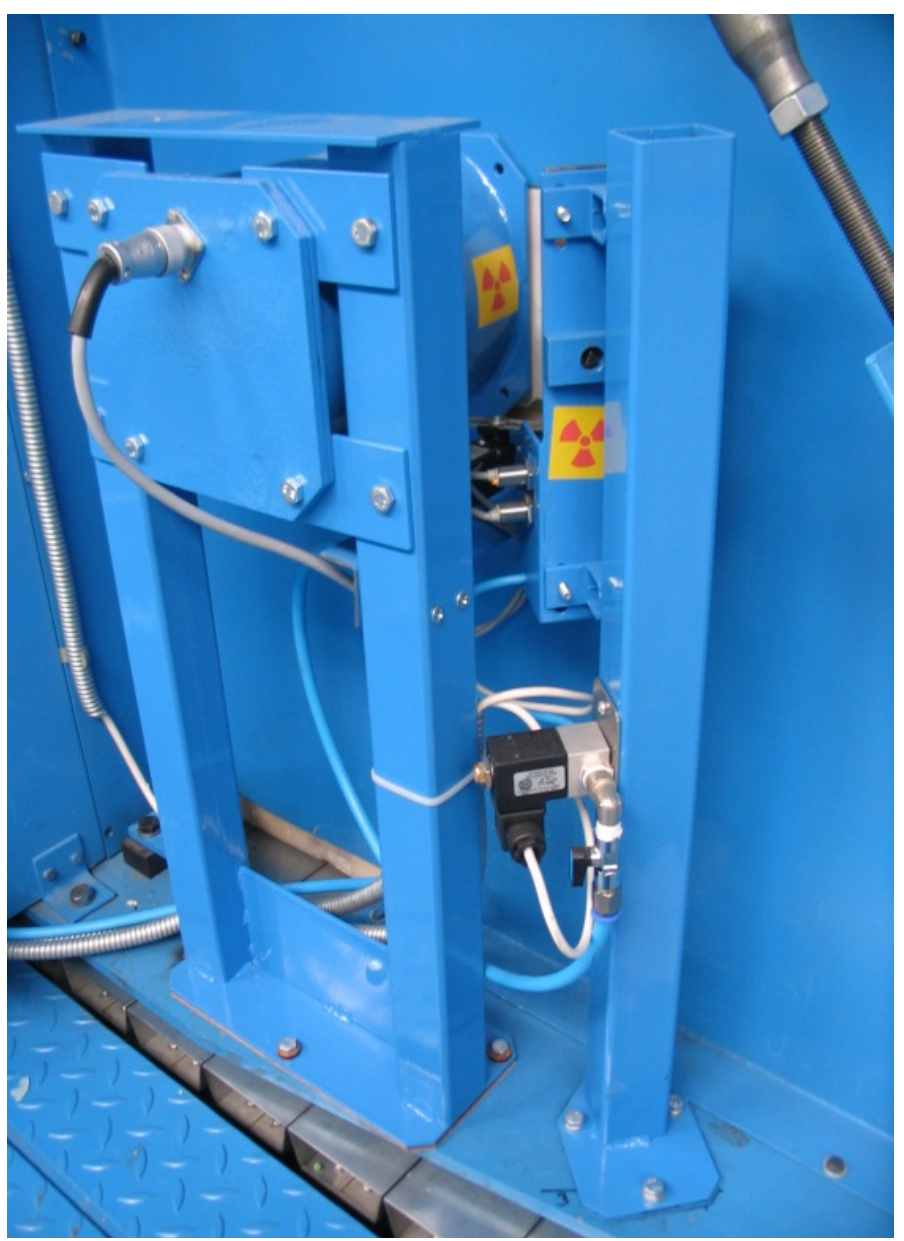

Figure 22. Backscattering densitometer for PE foam [25]. 
range, while point level measuring devices (isotopic level relays) are used to signal the exceeding of a given level by the measured medium at the meter head installation location. In these gauges, the measured medium completely covers (cuts off) part of the radiation beam. Linear and point level gauges do not differ in principle, but only in terms of collimation of the radiation beam and the detector's active length.

TDI-xx-SF-Analysis of the composition of the medium and coating thickness.

These meters use fluorescent method for their work. They are used to analyze the percentage of various elements in the measuring medium (e.g. iron, zinc, lead, nickel, copper), as well as to measure the thickness of thin coatings covering thicker substrates.

\subsection{POLON-IZOT Sp. z o.o. [26]}

Michała Spisaka 31, 02 - 495 Warszawa, http://www.polonizot.pl.

POLON-IZOT is a leading domestic producer of apparatus using X-rays and isotopic phenomena. It can boast over 50 years of technical achievements. Polon-Izot has many years of experience in the field of construction and production of measuring devices, control systems for technological processes, metrology (laboratory measurements, off-on line) and apparatus for the needs of environmental

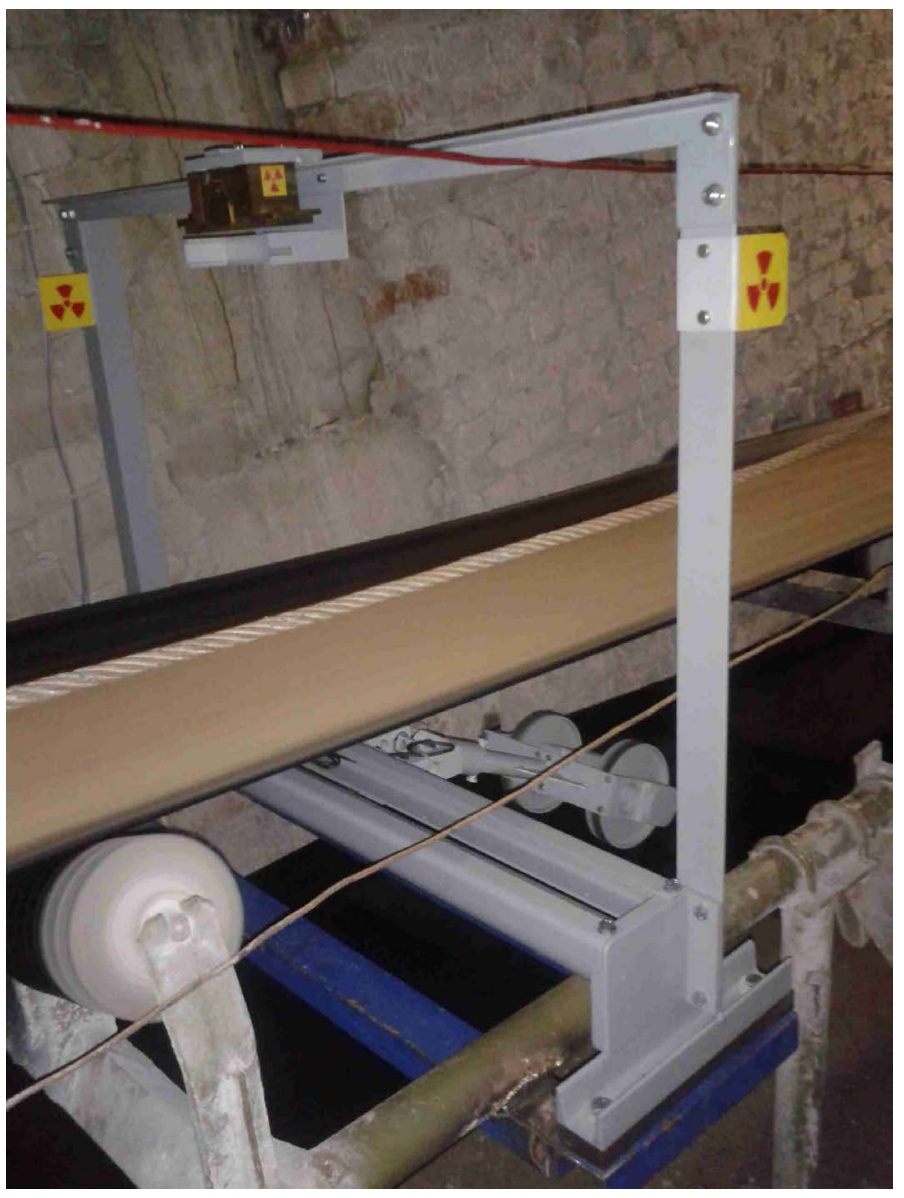

Figure 23. Nucleonic weighers [25]. 
protection. They provided control and measurement devices to over 300 companies in Poland and abroad.

Industrial dust gauge

To measure the concentration of dust in the air, the device uses the attenuation of ionizing radiation through the measured medium. In principle, the system is therefore a density meter. To extract the dust content from the sample, it is necessary to know the current air density, which is calculated on the basis of the values collected by the temperature, pressure and humidity meters. The collimated radiation beam emanating from the container with the isotope source passes the measurement space and goes to the detection unit, where the intensity of radiation is converted into an electrical signal in the detector. The signal is amplified and processed into a digital form-in this post it goes through the serial interface to the controller, which calculates the concentration of dust based on the difference in air density and the density of the measurement space. The controller has outputs for switching on the visual and acoustic signaling in case of exceeding the permissible dust levels (Figure 24).

Area of applications: measurement of industrial concentrations of dust in channels and chimneys; measurement of dust concentrations in hazardous areas explosion; processes related to heat treatment in furnaces industrial; monitoring of filters; chemical, foundry and metallurgical industry. Technical specifications of MPP are shown in Table 6.

Level gauge

The entire class of level recording devices is based on the tendency of the material to reflect or absorb radiation. The main advantage of the level meter is the

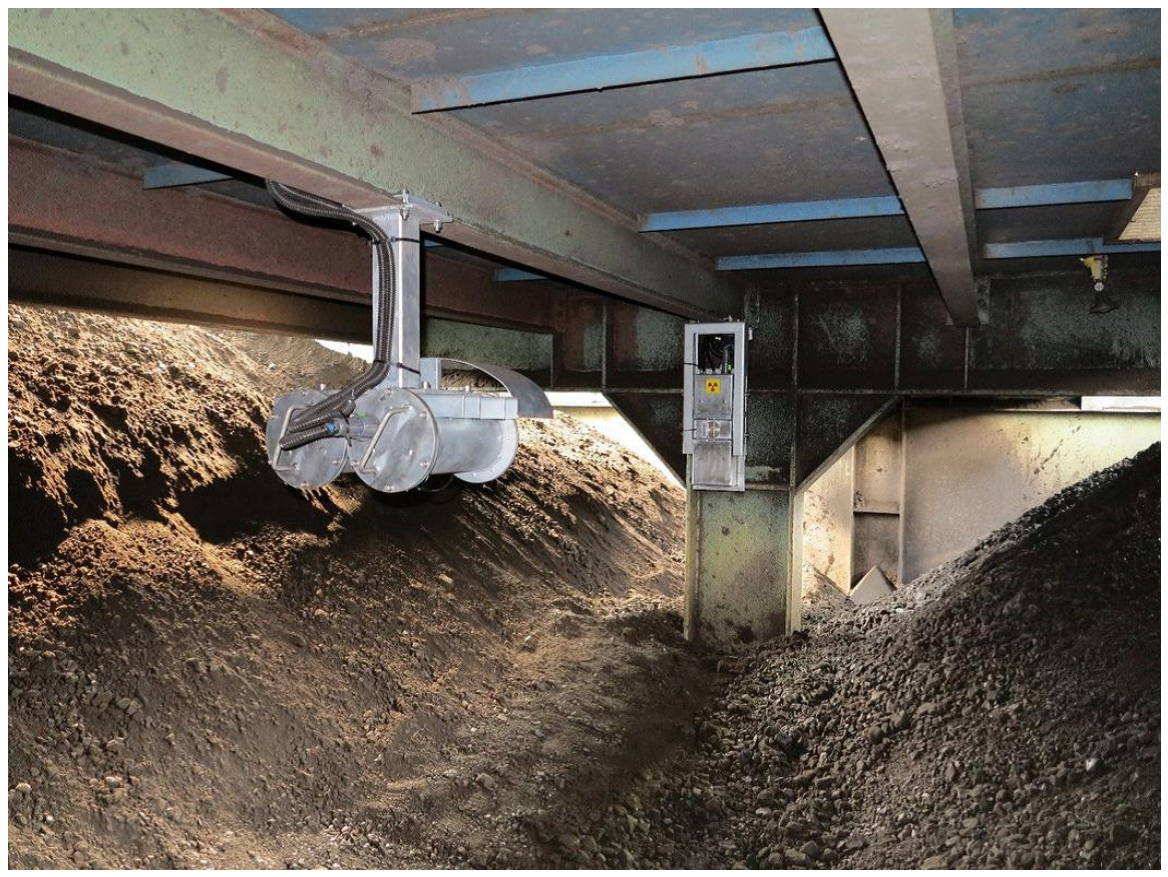

Figure 24. Dust monitoring system in the mine. Detector and radiation emitter (ATEX performance) [26]. 
lack of moving parts and the ability to detect level without physical contact with the tested medium. The gauge registers changes in the radiation dose rate as a result of the presence of the medium in the measurement space between the isotope source and the detector. The gauges are used for contactless, continuous level measurements of liquid, powders, aggregates and solids.

Area of applications: measuring the level of concentrated acids, bases, salt solutions and suspensions; monitoring the crystallization process and polymerization; measuring the level of solids including aggregates on conveyor belts; powder level measurement; measurement of filling level of tanks, cylinders. Technical specifications of MP are shown in Table 7.

Industrial gauges of thickness and basis weight

The industrial (on-line) thickness and basis weight gauges operate in a non-contact manner and do not destroy of the tested sample (Figure 25). The partial absorption of radiation by the sample is used for the measurement-after passing through the tested medium falls on detector that converts radiation

Table 6. Technical specifications of MPP type gauges [26].

\begin{tabular}{ccc}
\hline MPP-xx & $\begin{array}{r}\text { Measurement } \\
\text { range }\left[\mathrm{g} / \mathrm{cm}^{3}\right]\end{array}$ & Function \\
\hline 01 & $0-60 \quad \begin{array}{r}\text { The system of continuous measurement of coal dust concentration, } \\
\text { composed of three density gauges type GM-01C, intended for application } \\
\text { in storage rooms, mines, etc. }\end{array}$ \\
\hline
\end{tabular}

Table 7. Technical specifications of MP type gauges [26].

\begin{tabular}{cccc}
\hline MP-xx & $\begin{array}{c}\text { Measurement } \\
\text { range [mm] }\end{array}$ & Isotope used & Function \\
\hline 01 to 04 & - 18,000 & Cs-137, Co-60 & $\begin{array}{c}\text { measurement and signalling of exceeding the } \\
\text { set level in tanks, clogging of through } \\
\text { channels, etc. by a process medium }\end{array}$ \\
\hline
\end{tabular}

Figure 25. Thickness gauge of plastic pipes walls, MM-04 type [26]. 
changes into a signal electric. Changing the thickness or basis weight of the measured material changes the current of the detector that is sent to microprocessor controller. The information provided in real time influence for increasing productivity and saving of raw materials. The online meters allow remote control production process, often under extreme conditions, e.g. at high temperature, in high humidity or in large dust (Figure 26). Technical specifications of MM are shown in Table 8.

Industrial density and/or concentration gauges

Emitted ionizing radiation is absorbed when passing through the tested material. The level of absorption depends on the length optical path which overcomes the radiation in a given substance and from the parameters of the substance:

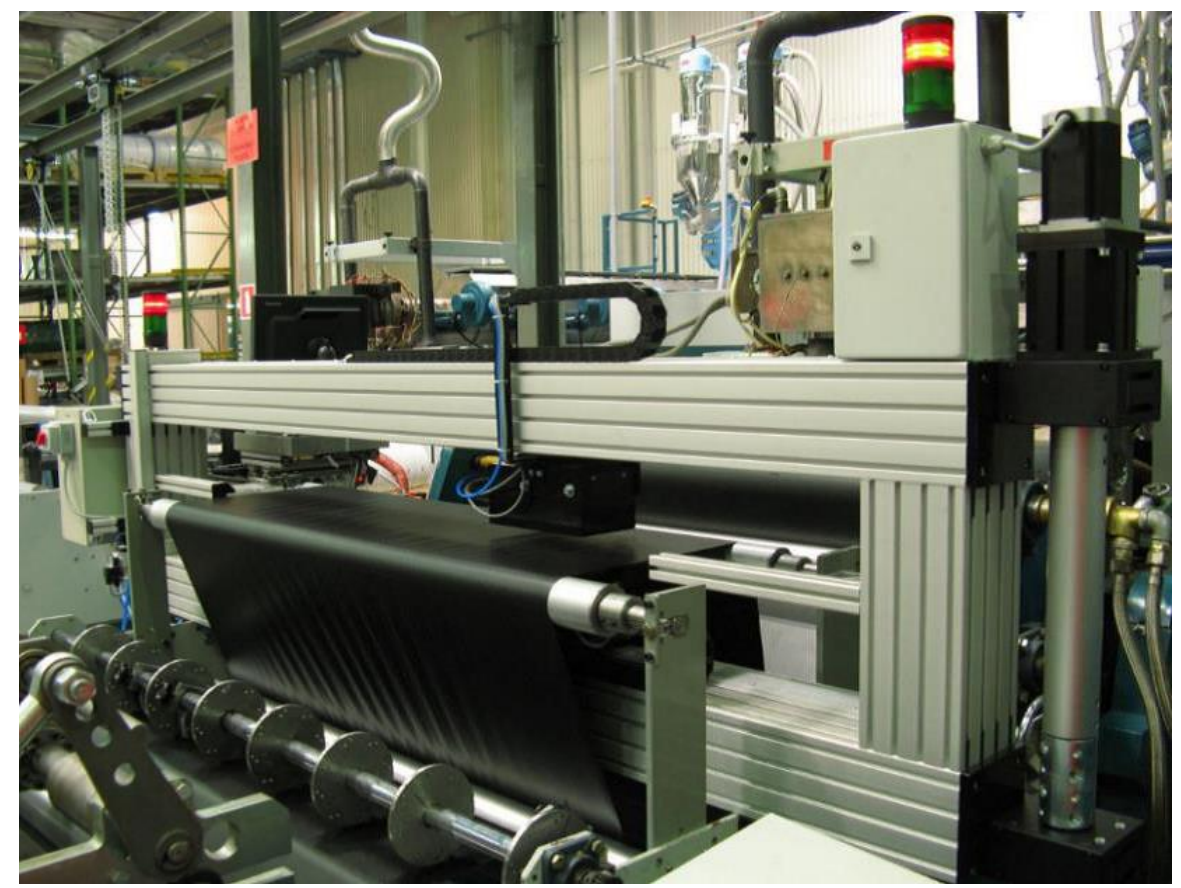

Figure 26. Radiometric profile meter-head with traverse, MM-06 type [26].

Table 8. Technical specifications of MM type gauges [26].

\begin{tabular}{|c|c|c|c|}
\hline MM-xx & Measurement range $[\mathrm{mm}]$ & $\begin{array}{l}\text { Measurement range } \\
{\left[\mathrm{g} / \mathrm{m}^{2}\right]}\end{array}$ & Function \\
\hline 02 & $0.1-8.0$ & - & Rolled sheets thickness measurement \\
\hline 03 & - & $250-950$ & $\begin{array}{c}\text { Basis weight of paper, cardboard, mineral wool, fiberboard, } \\
\text { non-woven, chipboard, etc. }\end{array}$ \\
\hline 04 & $\begin{array}{l}1.8-60.0 \text { (for outer diameter } \leq 630 \\
-1200 \mathrm{~mm} \text { depends on thickness) }\end{array}$ & - & $\begin{array}{l}\text { Surrounding, continuous measurement of the plastic pipes wall } \\
\text { thickness during the production process, adapted for operation with } \\
\text { different types of extruding machines }\end{array}$ \\
\hline 06 & $0.01-4.0$ & - & $\begin{array}{l}\text { Measuring the thickness of film, lining, rubber and similar materials } \\
\text { using a traverse head across the band }\end{array}$ \\
\hline 08 and 09 & $0.5-10.0$ & - & Thickness across the glass pane with a traverse head \\
\hline 12 & $0.02-0.5$ & - & Thickness of rolled steel sheets \\
\hline
\end{tabular}


density, concentration, chemical composition, temperature (Figure 27 and Figure 28). The constant distance of the emitter from the detector allows the measurement of the measured parameters in radiation absorption function in the material under study. The device allows non-contact measurement of the density or concentration of liquids in pipelines or tanks with complete filling of the measuring space. They can be used in the building industry (lime and gypsum slurries), sugar and alcohol (diffusion juice) and related industries. The EX is designed for applications in potentially explosive areas. Technical specifications of GM are shown in Table 9.

Nucleonic weighers

Provide contactless mass measurement of bulk materials transported on belt conveyors in the chemical, mining, food, and other industries. Technical specifications of MPP are shown in Table 10.

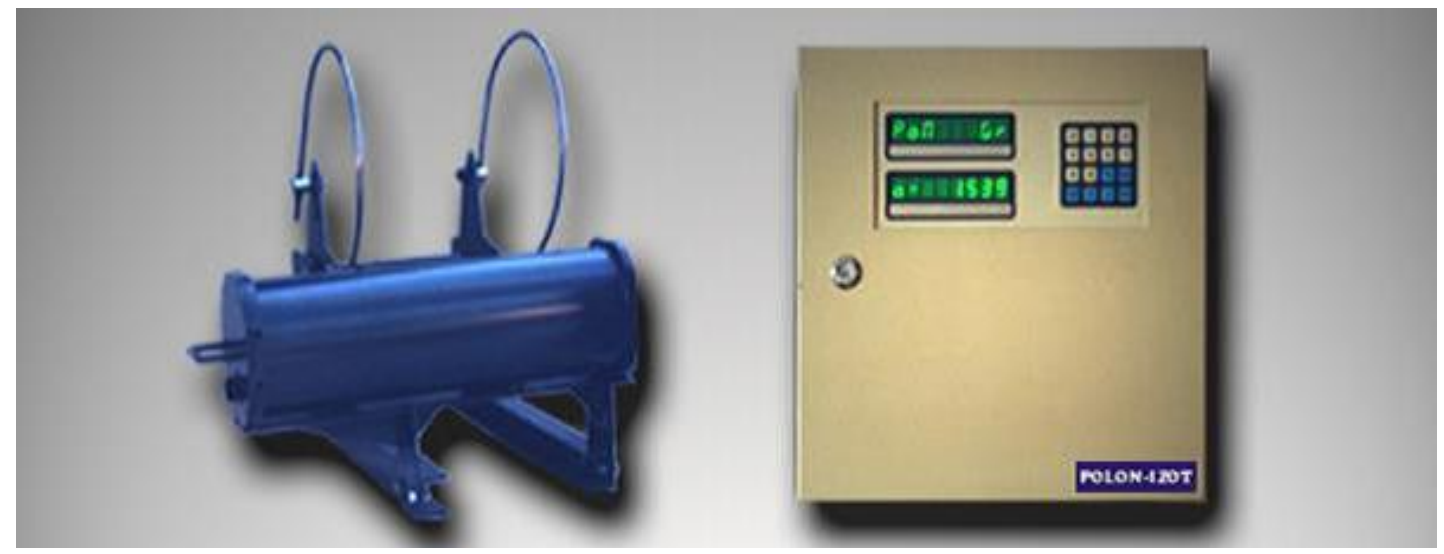

Figure 27. Density gauge GM-01 type [26].

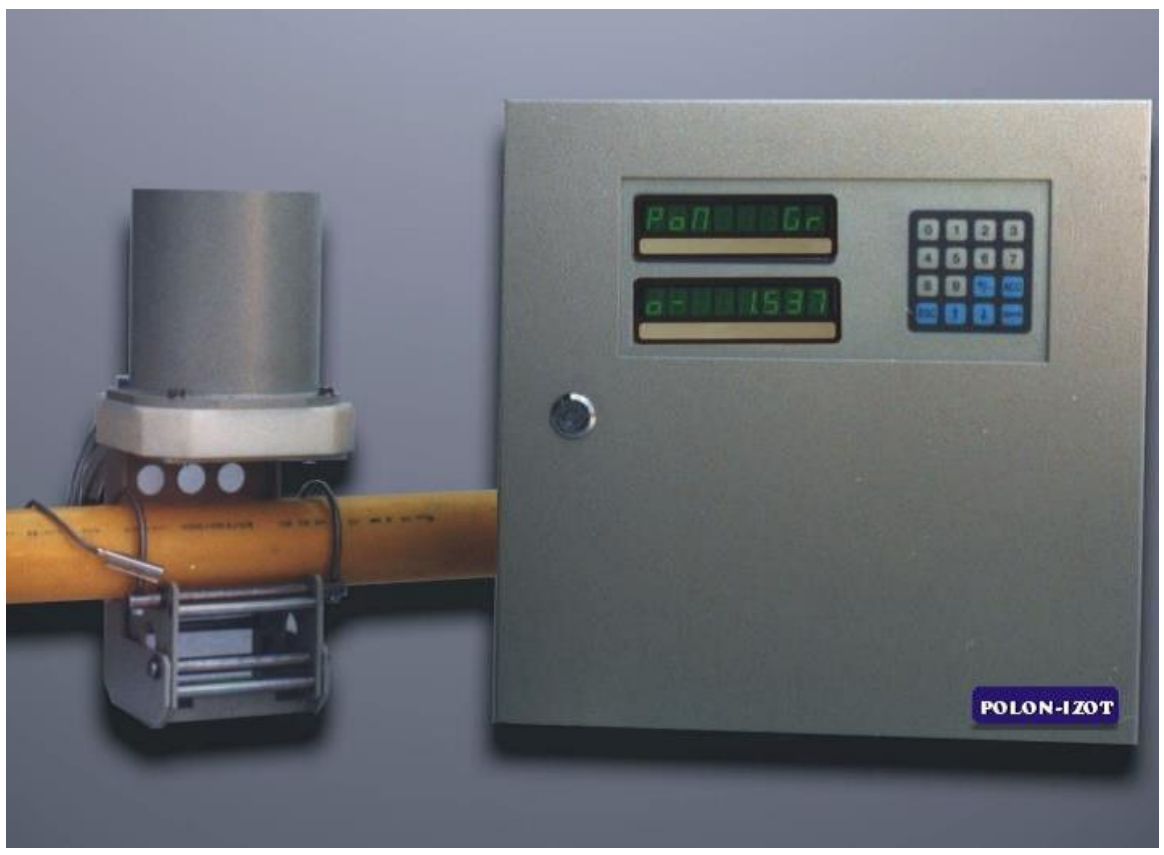

Figure 28. Concentration gauge, GM-06 type [26]. 
Table 9. Technical specifications of GM type gauges [26].

\begin{tabular}{cccc}
\hline GM-xx & Measurement range $\left[\mathrm{g} / \mathrm{cm}^{3}\right]$ & $\begin{array}{c}\text { Outer diameter } \\
\text { of pipe }[\mathrm{mm}]\end{array}$ & $\begin{array}{c}\text { Temperature } \\
\text { measuring range }\left[{ }^{\circ} \mathrm{C}\right]\end{array}$ \\
\hline 01 & $0.6-3.5$ & $100-298$ & $-25-200$ \\
02 & $0.6-3.5$ & $300-406$ & $-25-200$ \\
04 & & $40-75$ & $0-100$ \\
06 & $0.7-1.6$ (or the corresponding & $40-75$ (up to 250 & $-25-200$ \\
01 or 02EX & percentages of concentration) & for special design) & \\
& $0.6-3.5$ & $100-298$ (for 01) & $-25-200$ \\
\hline
\end{tabular}

Table 10. Technical specifications of GM type gauges [26].

\begin{tabular}{ccc}
\hline TW-xx & Measurement range $[\mathrm{kg} / \mathrm{m}]$ & Typical yield $[\mathrm{Mg} / \mathrm{h}]$ \\
\hline 03 & $3-20$ (for $500 \mathrm{~mm}$ belt) & $20-300$ \\
& $10-50$ (for $650 \mathrm{~mm}$ belt) & $100-650$ \\
04 & $20-80$ (for $800 \mathrm{~mm}$ belt) & $120-1000$ \\
05 & $30-120$ (for $1200 \mathrm{~mm}$ belt) & $180-1500$ \\
\hline
\end{tabular}

\subsection{Ośrodek Techniki Jądrowej Polon Wrocław Sp z o. o. ("POLON" Nuclear Technology Centre in Wrocław, Ltd.) [27]}

Na Grobli 6, 50-421 Wrocław, http://www.polon-otj.pl.

In terms of the subject of its operation and continuity of obligations, it is a successor to the "Polon" Department of Applied Nuclear Techniques in Wrocław (operating in the years 1965-1992). The department was established in the sixties with the mission to implement isotopic techniques in the industry. It successfully performed the tasks involving designing, implementation and maintenance of industrial equipment containing sources of ionizing radiation. Along with the emergence of fire detection systems, in which smoke detectors containing radioactive material are an important element, the scope of business operation was expanded to include the design, construction and maintenance of fire detection systems. In 1992, a group of the Company's employee transformed the state-owned company into a limited liability company through employee privatization. The Company continues its activity in its traditional areas, however, due to the natural evolution of the market demand, it has expanded the range of the services offered that now include: development, production of electronic devices made to single orders of the customers; design, installation, maintenance of building security systems, i.e. hazardous gas detection equipment, intrusion alarm systems, smoke ventilation systems, access control systems and CCTV systems.

Signalling Devices: ISP-03S, ISP-02G, ISP-01 (Figure 29).

They are used for the non-contact control of tanks filling with liquid or loose material. Isotopic signaling devices are used to perform tasks that are impossible or very difficult to accomplish with other measurement methods. With proper selection of the source of radiation, it is possible to control the presence of the 
medium enclosed in the shell, e.g. $0.5 \mathrm{~m}$ of concrete or $200 \mathrm{~mm}$ of steel.

ISP-01, ISP-02G are the Geiger counters, moreover 02G type can be mounted in potentially explosive areas. The special feature of the ISP-03S signaling device is its scintillation detector $\mathrm{NaI}(\mathrm{Tl})$ instead of the G-M meter, which makes it about 15 times more sensitive than ISP-01 for 60Co sources and about 50 times more sensitive for $137 \mathrm{Cs}$ sources. For example, the ISP-01 radiometric probe is installed in the SOLBET production facility and controls the cement tank filling system.

Isotopic Level Transmitter IPSPZ-3 (Figure 30).

Isotopic level signal transmitter is designed for non-contact measurement of the level of various substances in tanks. In cooperation with the controller, it allows for precise level stabilization, and thus simplifies the technological process control. If the emergency level is exceeded, it activates the tank filling blockade. Geiger counters are used as the radiation detector. Their number and position of

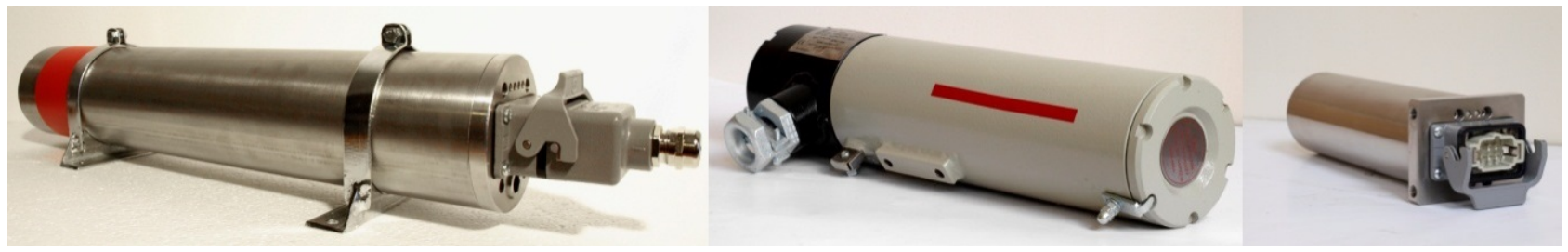

Figure 29. ISP-03S, ISP-02G ISP-01 [27].

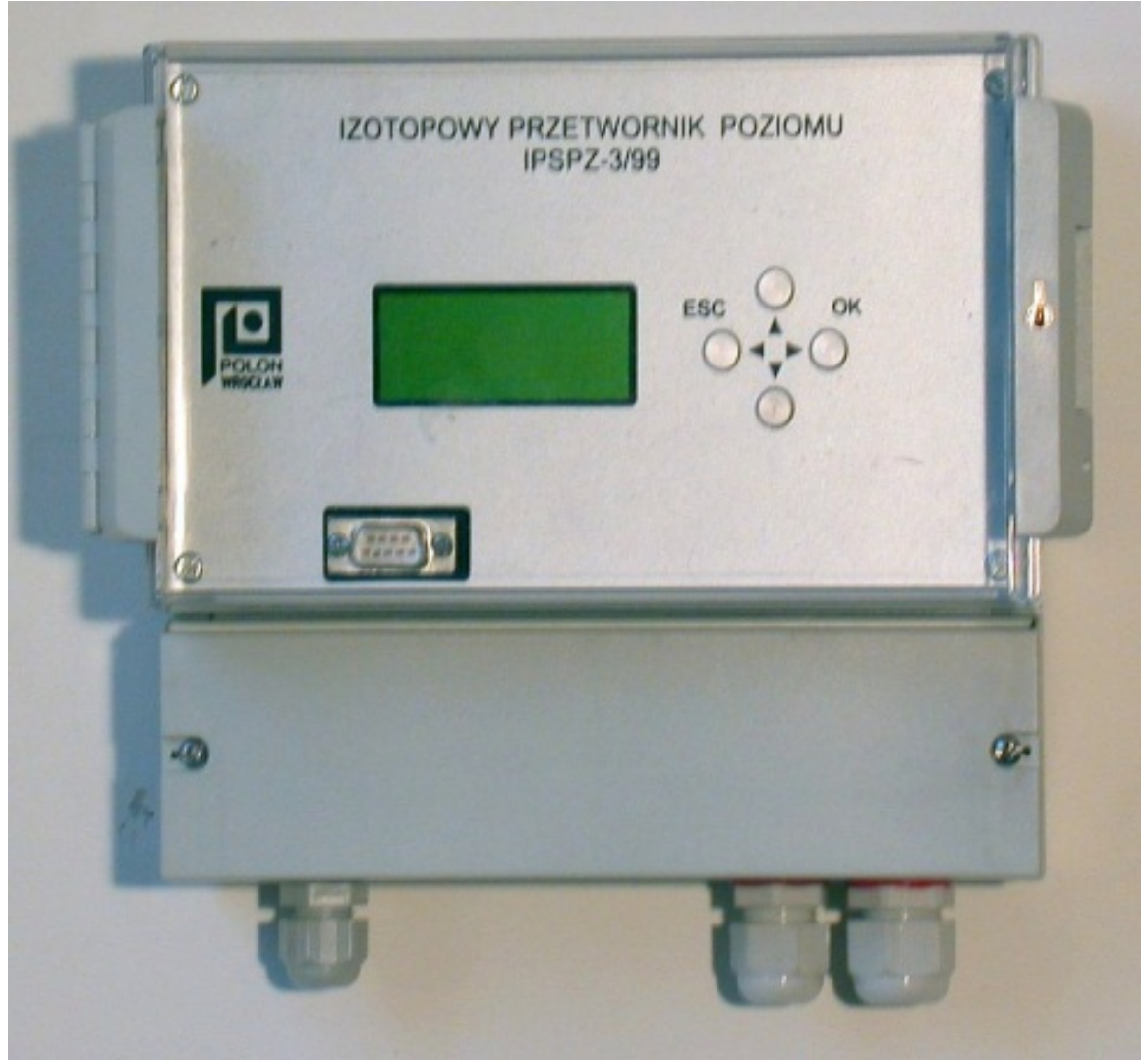

Figure 30. IPSPZ-3 [27]. 
the probe depend on the measurement task.

\subsection{Tranz-Tel sp. z o.o. [28]}

Centralna 37, 43-210 Kobiór, http://www.tranztel.com.pl.

TranzTel designs, implements and maintains advanced-intrinsically safe-systems and devices for various industries. The Company offers one isotopic meter of its own production-density gauge. Installation on pipes with different diameters is possible. Wide application in industry: chemical, petrochemical, food and pharmaceutical industry, mining, environmental protection, etc. For example, together with other meters, it is used in the automatic regulation of heavy liquid in mining industry.

Technical specifications:

- Closed gamma radiation source: Cs-137,

- Source activity selected individually: 0.5 - $15 \mathrm{GBq}$,

- Outer diameter of pipes: 50 - $500 \mathrm{~mm}$,

- Measuring range: $0.5-5.0 \mathrm{~g} / \mathrm{cm}^{3}$.

Companies involved in non-destructive testing, including gamma radiography.

- NDT System S. Twardowskiego 21, 01-643 Warszawa, http://www.ndt-system.com.pl,

- NDTEST Sp. z o.o. Sztabowa 10, 04-283 Warszawa, http://www.ndtest.com.pl,

- Badania Nieniszczące Górka Dawid Górka Podgórna 61, 62-064 Plewiska, http://www.ndtgorka.com.pl,

- "Energomontaż-Północ - Technika Spawalnicza i Laboratorium" Sp. z o.o.,

- Chełmżyńska 194, 04-464 Warszawa, http://www.eptsil.pl,

- Laboratorium Badań Nieniszczących "H-GAZ" Sp. z o.o. Powstańców Listopadowych 2B, 35-606 Rzeszów, http://www.h-gaz.com.pl.

\section{Acknowledgements}

This paper has been prepared in the frame of International Atomic Energy Agency TC Regional Project RER1020 "Developing Radiotracer Techniques and Nuclear Control Systems for the Protection and Sustainable Management of Natural Resources and Ecosystems" and co-financed by Ministry of Science and Higher Education (Poland) project-416582/W81 /IAEA/2018.

\section{Conflicts of Interest}

The authors declare no conflicts of interest regarding the publication of this paper.

\section{References}

[1] Cameron, J.F. and Clayton, C.G. (1971) Radioisotope Instruments, Pergamon Press, Oxford. https://doi.org/10.1016/B978-0-08-015802-0.50007-0 
[2] Chmielewski, A.G. (2008) Role of Nuclear and Radiation Technologies in Oil, Gas and Coal Mining, Distribution and Power Sector Applications. Nukleonika, 53, 55-59.

[3] National Atomic Energy Agency (2017) Nnual Report Activities of the President of the National Atomic Energy Agency and Assessment of Nuclear Safety and Radiological Protection in Poland in 2016. Warsaw.

[4] Thereska, J., Rogowski, M. and Smolinski, T. (2018) IAEA-RER1020 Project to Enhance and Consolidate Regional Capabilty in Online Industrial Process Diagnosis, Optimization and Troubleshooting, Using Radiotracers and Sealed Source Techniques. Instytut Chemii I techniki Jądrowej.

http://www.ichtj.waw.pl/ichtj/publ/REPOZYTORIUM/2018/konferencje/RER1020I AEA2018.pdf

[5] Smoliński, T., Rogowski, M., Pyszynska, M., Brykała, M. and Chmielewski, A.G. (2018) Nuclear Techniques for the Study Hydrometalurgical Procceses to Be Applided in Copper Industry; I. Application of $64 \mathrm{Cu}$ Radiotracer for Investigation of Copper Ore Leaching. Nukleonika, 63, 123-129.

https://doi.org/10.2478/nuka-2018-0015

[6] Rogowski, M., Smoliński, T., Pyszynska, M., Brykała, M. and Chmielewski, A.G. (2018) Nuclear Techniques for the Study Hydrometalurgical Procceses to Be Applided in Copper Industry; II. Application of Radiotracers for Copper Leaching from Flotation Tailings. Nukleonika, 63, 131-137.

https://doi.org/10.2478/nuka-2018-0016

[7] Miśkiewicz, A. and Zakrzewska-Kołtuniewicz, G. (2018) The Application of the Radiotracer Method for the Investigation of the Cake Layer Formation on the Membrane Surface in the Cross-Flow Flat-Sheet Membrane Module. Desalination and Water Treatment, 128, 228-235. https://doi.org/10.5004/dwt.2018.22866

[8] POLATOM (2019). https://www.polatom.pl/en/produkty-uslugi

[9] National Centre for Nuclear Research (2019). https://www.ncbj.gov.pl/en/o-nas/maria-research-reactor

[10] Kraś, J., Nobis, C. and Myczkowski S. (2008) Leakage Control Methods for Metal Underground Tanks and Tanks Placed on Hardened Soil with the Use of Radioactive Tracers. Nukleonika, 53, 137-140.

[11] Institute of Nuclear Chemistry and Technology (2019). http://www.ichtj.waw.pl/ichtj/market/m-eng/dep_01/leak.htm

[12] Palige, J., Roubinek, O., Wawryniuk, K., Modzelewski, Ł., Jakowiuk, A., Dobrowolski, A., Drewniak, ł. and Ciężkowska, M. (2014) Badania procesu fermentacji metanowej z wykorzystaniem metod radioznacznikowych i technik gamma skaningu [Research on the Methane Fermentation Process Using Radioactivity Methods and Gamma Scanning Techniques]. Inżynieria i Aparatura Chemiczna, 53, 280-281

[13] http://www.cttemag.pl/

http://www.ibemag.pl/pl/

[14] Polish Atomic Law. http://prawo.sejm.gov.pl/isap.nsf/DocDetails.xsp?id=wdu20010030018

[15] OECD (2015) Nuclear Legislation in OECD and NEA Countries, Regulatory and Institutional Framework for Nuclear Activities. https://www.oecd-nea.org/law/legislation/

[16] PAA. http://www.paa.gov.pl/strona-40-prawo_krajowe.html

[17] PAA. 
http://www.paa.gov.pl/strona-105-zezwolenia_na_dzialalnosc_ze_zrodlami.html

[18] Polish Norms and Radiological Standards.

https://pzn.pkn.pl/pzn-share/page/

[19] http://www.ichtj.waw.pl/drupal/

[20] Smolinski, T., Wawszczak, D., Deptula, A., Lada, W., Olczak, T., Rogowski, M., Pyszynska, M. and Chmielewski, A.G. (2017) Solvent Extraction of Cu, Mo, V, and $\mathrm{U}$ from Leach Solutions of Copper Ore and Flotation Tailings. Journal of Radioanalytical and Nuclear Chemistry, 314, 69-75.

https://doi.org/10.1007/s10967-017-5383-y

[21] Smoliński, T., Rogowski, M., Pyszynska, M. and Chmielewski, A.G. (2017) Metal Recovery Optimized by Radioisotope Methods. Odzysk Metali Optymalizowany Metodami Radioizotopowymi. GOSPODARKA ODPADAMI, 2/2017, 24-27.

[22] https://www.ncbj.gov.pl/en

[23] http://www.wilpo.pl/

[24] http://www.syskon.eu/firma/

[25] http://td-electronics.pl/

[26] http://www.polonizot.pl/

[27] http://www.polon-otj.pl/

[28] http://www.tranztel.com.pl/ 